\title{
THE GENUS STRANDESIA AND OTHER CYPRICERCINI (CRUSTACEA, OSTRACODA) IN THE WEST INDIES
}

\author{
PART I. TAXONOMY
}

\author{
by \\ NICO W. BROODBAKKER \\ Institute of Taxonomic Zoology, University of Amsterdam, \\ P.O. Box 20125, 1000 HC Amsterdam, The Netherlands
}

\begin{abstract}
SUMMARY
Seven new species and one new subspecies of the genus Strandesia s.l. Stuhlmann, 1888, are described. Four species reared by Sars (1901) from dried mud from Brazil are redescribed. The genera Acanthocypris Claus, 1892, and Neocypris Sars, 1901, are considered as subgenera of Strandesia s.l. Two species from Europe, formerly attributed to Cypricercus Sars, 1895, are redescribed. One of these, C. obliquus (Brady, 1868) was used as type-species for the erection of a new tribe and of the genus Bradleycypris by McKenzie (1982), but proves to be a member of the subgenus Neocypris of Strandesia s.l. Therefore Bradleycypris becomes a subjective synonym of Neocypris. On the other hand, Cypricercus fuscatus (Jurine, 1820) effectively shows the characters used by McKenzie for the characterization of Bradleycypris, and is selected here as type-species of the new genus Bradleystrandesia.
\end{abstract}

\section{RÉSUMÉ}

Sept espèces et une sous-espèce nouvelles du genre Strandesia s.l. Stuhlmann, 1888, sont décrites. Quatre espèces décrites par Sars (1901), élevées de vase sèche de Brésil, sont redécrites. Les genres Acanthocypris Claus, 1892, et Neocypris Sars, 1901, sont considérés commes sous-genres de Strandesia s.l. Deux espèces d'Europe, attribuées autrefois au genre Cypricercus Sars, 1895, sont redécrites. Une de ces espèces, $C$. obliquus (Brady, 1868), a été indiquée comme espèce-type du genre et de la tribu Bradleycypris par McKenzie, 1982, mais elle appartient au sous-genre Neocypris de Strandesia s.l.; Bradleycypris est donc un synonyme subjectif de Neocypris. Par contre, Cypricercus fuscatus (Jurine, 1820) montre effectivement les caractères

*) Report 34 is published in the same issue of this journal. attribués au genre Bradleycypris par McKenzie et est désigné comme espèce-type du genre nouveau Bradleystrandesia.

\section{INTRODUCTION}

The previous studies concerning the Ostracoda of the West Indies dealt with the genera Heterocypris and Hemicypris (Broodbakker, 1982; $1983 \mathrm{a} \& \mathrm{~b})$. The present paper is part of a study on the tribe Cypricercini, of which the genus Strandesia Stuhlmann, 1888, is the most rich in species. This genus, which is widespread throughout the world, especially the tropics, is probably polyphyletic, and has to be divided in several subgenera, which eventually could be attributed the status of genus. There is also confusion about several related genera, like Spirocypris Sharpe, 1903, Cypricercus Sars, 1895, and the recently described Bradleycypris McKenzie, 1982. Validity of, and differences between these taxa will be discussed. All species ascribed to Strandesia as far as they could be traced by the author, are listed in the appendix.

The genus Strandesia s.l. is represented by eight species in the West Indies and Venezuela. Seven of these are new species, and one is represented by a new subspecies. They will be described in this paper. The species are closely related to most species recorded by Sars (1901) from Brazil, as Neocypris, four of which will be 
redescribed in this paper. Two species from Europe assigned to Bradleycypris by McKenzie (1982) are restudied and discussed. An attempt is made to reclassify all species described or redescribed in the present paper, in subgenera.

\section{MATERIAL AND METHODS}

Most of the samples studied have been collected by the Amsterdam Expeditions to the West Indian Islands (1973-1982), and the expeditions of Dr. P. Wagenaar Hummelinck to many Caribbean islands (1936-1973). The samples from Cuba have been collected by Dr. L. Botosaneanu or Dr. T. Orghidan, in 1969, 1970 and 1973. Extensive descriptions of the caves sampled in 1969 in Cuba, can be found in Botosaneanu (1970). For further details about most other samples, the reader is referred to Stock (1979) and Wagenaar Hummelinck (1940 a \& b, 1953, 1981). The samples of the Amsterdam Expeditions, of Dr. P. Wagenaar Hummelinck, and of Dr. L. Botosaneanu are abbreviated in the sequel as $\mathrm{S}, \mathrm{WH}$, and $\mathrm{B}$, respectively. All material is deposited in the Zoölogisch Museum, Amsterdam (ZMA), except for the material from Sars, which is deposited in the Zoologisk Museum Oslo (ZMO).

The description of the chaetotaxy of the limbs is made according to the system of Broodbakker \& Danielopol (1982). The lengths of several segments and setae were measured, as well as carapace lengths. Measuring was done with a ruler on a sheet of white paper, on which the animals were projected by way of a camera lucida and a Reichert Diapan microscope. Slides were made according to the method of Danielopol (1982).

Every description of a species is followed by some taxonomic remarks, and by some remarks about its ecology. Ecology and variations in carapace length of Strandesia longula $\mathrm{n}$. sp. and $S$. stocki $\mathrm{n}$. sp. will be discussed in part II of this paper.

\section{TAXONOMY OF THE TRIBE GYPRICERCINI}

\author{
Family CYPRIDIDAE Baird, 1845 \\ Subfamily CYPRIDINAE Baird, 1845 \\ Tribe Cypricercini McKenzie, 1971b
}

The taxonomic system of Alm (1915) as adapted by Maddocks (1969) and Danielopol $(1976,1978)$ is used in dividing the order Cypridacea in families and subfamilies, the subfamily Cypridinae being divided in tribes, and not in other subfamilies, as in Hartmann
\& Puri (1974). Several genera of the tribe Eucypridini Bronstein, 1947, have later been placed in other tribes. The genera Strandesia (incl. Neocypris and Acanthocypris), Cypricercus, Spirocypris, and Tanycypris Triebel, 1959, were placed in the tribe Cypricercini by McKenzie (1971b). Furthermore, I propose to add Astenocypris Müller, 1912, to this tribe (cf. Victor \& Fernando, 1981b: 115-116) because of the presence of a dorsal loop in the furcal attachment.

There is a great deal of confusion in literature regarding the genera belonging to the tribe Cypricercini. Many authors discussed the genera Cypricercus and Strandesia: Müller (1912) synonymized Cypricercus with Strandesia, a view which was not accepted by Sars (1924). Sars (1928) even attributed four European species Cypris fuscata Jurine, 1820; C. affinis and C. hirsutus, both Fischer, 1851; and C. obliquus Brady, 1868 - to his South African genus Cypricercus. Tressler (1950) separated Cypricercus from Strandesia on the ground of invalid characters. Klie discussed the genus Strandesia in several publications. Fox (1964) described the furcal attachments of some Strandesia and Cypricercus species. Sywula (1972) stated that there were no recognized characteristics allowing separation of the species of both taxa. Victor \& Fernando (1981 a \& b) described and redescribed a number of Asian Strandesia s.l. species.

The most recent discussion on the problem was by McKenzie (1982), who erected a new tribe, Bradleycypridini, consisting of species from Europe and North America, formerly ascribed to the genera Cypricercus and Spirocypris. McKenzie (1982) confined the genus Cypricercus s. str. to the original four species from South Africa, which he considered to be a separate lineage within the tribe Cypricercini, because of the relatively thicker shelled, oval elliptical valves, which, as in Strandesia s.l., are distinctly asymmetrical, and have the inner lamellae broad anteriorly, and narrow posteriorly. Discussion of the genus Cypricercus s. str., as defined by McKenzie (1982) remains beyond the scope of this paper because of lack of South African material. 
McKenzie separated the tribe Bradleycypridini from the Cypricercini on account of their markedly different chitin support of the furca, and because of the furcal attachment "in which the proximal eyelet is on the dorsal branch and not in the proximal fork itself', and because of the median shaft being slender, in contrast to the stout median shaft in Cypricercini. He also stated that the furca tends to be weakly curved, not being distinctly flexuous as in Cypricercus s. str. and Strandesia. As type-species of the genus Bradleycypris he chose Cypricercus obliquus (Brady, 1868). Fox (1964) illustrated the furcal attachment of $C$. obliquus, which strikingly resembles that of other species of Strandesia s.l., and is not as described for Bradleycypris. Therefore I have checked some Dutch specimens of $C$. obliquus, which appeared to have the Strandesia type of attachment indeed (fig. 14K). C. fuscatus and C. affinis, however, have the Bradleycypris type of furcal attachment, as is illustrated in Rome (1969: 182, fig. 7), and in Fox (1964: 627, fig. 3). Furthermore, $S$. trispinosa, of which a subspecies is described in the present study, has a Bradleycypris type of furcal attachment, and some of the species described by Victor \& Fernando (1981) also have furcal attachments resembling that of Bradleycypris.

Summarizing, it seems that the characters mentioned by McKenzie (1982) are not important enough to justify the erection of a new tribe, but at most of a new genus. Furthermore, the species chosen by McKenzie as type-species for Bradleycypris is proven to belong to a subgenus of Strandesia. In order to retain the group of species showing the characters used by McKenzie for the characterization of Bradleycypris, the new genus Bradleystrandesia is erected here.

Further research is needed to prove if the genus Bradleystrandesia is confined to Europe and North America only. If $C$. obliquus is accepted to belong to another subgenus of Strandesia s.1., this will mean that Strandesia s.l., Bradleystrandesia excluded, is not confined to the tropical and subtropical part of the world, but occurs in the colder parts of the northern hemisphere as well.
Genus Strandesia s.l. Stuhlmann, 1888

Diagnosis. - The most recent comprehensive description was provided by Victor \& Fernando (1981), which is summarized here.

Length of carapace up to $2.5 \mathrm{~mm}$. In lateral view, valves are moderately elongate, subelliptical or subovate, and rarely subtriangular. Hinge adont. Left valve overlaps the right. Selvage variable. Inner duplicature wider anteriorly than posteriorly. Pore canals simple. Dorsal alae or spines, marginal and lateral spines, are not unusual. Valve surface is smooth, scaly, reticulate, striate or punctate. Natatory setae of the second antenna well developed, not reaching or reaching the tips of the terminal claws. The terminal claws are as long as or longer than $\mathrm{E}$ (II + III), and slender. The mandibular palp has $\alpha, \beta$ and $\gamma$ setae. The maxilla has two a, b and d setae, the branchial plate of the exopodite bears six plumose setae. The maxillular spines of Mastic 3 are usually serrate. Furcal rami long, slender and symmetrical, the ramus being 14 to 30 times as long as wide. Posterior seta short, less than half the length of $G_{p}$. Anterior seta occasionally short, but mostly longer than half the length of $G_{a}$ or nearly as long as $\mathrm{G}_{\mathrm{a}}$. Posterior margin of ramus usually bristled or spinose, and occasionally smooth. Furcal attachment with a distinct dorsal loop or eyelet, which is mostly triangular. The length of the ventral branch is variable. Of most Strandesia populations only females are known. The sperma ducts in males form a dense coil in the anterior part of each valve, a character shared with the other Cypricercini.

Synonymies and subgenera. - The genus Strandesia was briefly but clearly described by Stuhlmann (1888), and later more extensively redescribed by Vávra (1895). This means that Strandesia Stuhlmann, 1888 , is not a nomen nudum, as indicated by Hartmann \& Puri (1974), Victor \& Fernando (1981), and most other authors. Moreover, the genus Acanthocypris was described by Claus in 1892, and not in 1895, as most authors indicate. The typespecies, Acanthocypris bicuspis, proved to belong to Strandesia. 
Sars (1901) described the genus Neocypris for six species from Brazil, but he did not indicate a type-species. One of these six species, Neocypris gladiator, proved to be synonymous with Acanthocypris bicuspis. The other five species, of which four will be redescribed in the present paper, also belong to Strandesia s.l.

The names Acanthocypris and Neocypris will here remain in use for two subgenera, which will be defined after the description of the species from the Caribbean.

\section{DESCRIPTION OF THE CARIBBEAN SPECIES}

Strandesia longula $\mathrm{n}$. sp.

(Figs. 1, 2)

Material. - Holotype: one female (ZMA Ost. 150.816A). Paratypes: 14 dissected females and about 250 undissected females (ZMA Ost. 150.816B).

Type-locality: S 78/205-206, Haiti, Dépt. de l'Ouest; a hole and a well between Gressier and Léogâne, near the rhum distillery $\left(18^{\circ} 32^{\prime} 27^{\prime \prime} \mathrm{N} 72^{\circ} 33^{\prime} 50^{\prime \prime} \mathrm{W}\right)$; for both: water table at $5 \mathrm{~m}$, water depth 1-1.5 m; chlorinity 40 $\mathrm{mg} / \mathrm{l}$; Cvetkov net; hole in black soil, well in stone; 5-V-1978. Accompanying fauna: Cyclopidae, Mosquito larvae. Accompanying Ostracoda: Strandesia stocki n. sp., Chlamydotheca unispinosa (Baird, 1862), Caribecandona trapezoidea Broodbakker, 1983c.

Other stations will be listed in part II of this paper. The species is most common in Haiti and the Bahamas.

Geographical distribution known. Curaçao; Bonaire; La Désirade; St. Martin; St. Eustatius; Tortola and Culebra (Virgin Islands); Haiti; Cuba; Grand Cayman; Providenciales (Caicos Islands); Mayaguana, Crooked Island, San Salvador and Eleuthera (Bahamas).

\section{Description}

Only females of this species have been found. It is therefore supposed to be parthenogenetic in this region.

Relative lengths of segments and part of the setae of most appendages are given in table $I$.

Carapace (figs. 1, 2A):

The carapace is smooth, sparsely hairy, and greenish transparent in life. Hinge adont. Mus- cle scars as typical of the Cypridinae. In dorsal view greatest width in the middle, being $35 \%$ of the length. In lateral view greatest height in the middle, being $45 \%$ of the length. Left valve slightly larger than the right one. Carapace moderately elongate, subelliptical. The dorsal margin is slightly bent and passes smoothly in the broadly rounded anterior and posterior margins. Ventral margin slightly sinuate. Duplicature wider anteriorly than posteriorly, which is best visible in fig. 1. Marginal pore canals distinct anteroventrally, over a short distance in the right valve, and over a longer distance in the left valve. Flange slightly conspicuous, only in the right valve. Selvage narrow in both valves. Anteroventrally there is a slight lip-like projection in the right valve, which seems to be characteristic of most Strandesia species.

The mean length of the left valve is $1.59 \pm$ $0.06 \mathrm{~mm}(n=14)$, and of the right valve 1.56 $\pm 0.06 \mathrm{~mm}(n=14)$, and the mean height of the left valve is $0.72 \pm 0.03 \mathrm{~mm}(n=13)$, and of the right valve $0.71 \pm 0.03 \mathrm{~mm}(n=12)$, in the type-locality. The mean length of undissected specimens in the type-locality is: $\mathbf{1 . 5 5}$ $\pm 0.05 \mathrm{~mm}(n=81)$, carapace length ranging from 1.47 to $1.69 \mathrm{~mm}$. The mean lengths in other stations range from 1.16 to $1.53 \mathrm{~mm}$, which means that the specimens from the typelocality are the largest. The differences in carapace length will be discussed in part II of this paper.

Antennule (A 1) (fig. 2C):

I: A- $1 m(\mathrm{pu}), \mathrm{P}-2 m(\mathrm{pu}) / \mathrm{II}: \mathrm{A}-1 s(\mathrm{pu}), \mathrm{P}-\mathrm{r} / \mathrm{III}$ : $\mathrm{A}-1 s(\mathrm{pu}), \mathrm{P}-1 s(\mathrm{pu}) / \mathrm{IV}: \mathrm{A}-2 l, \mathrm{P}-2 s(\mathrm{pu}) / \mathrm{V}: \mathrm{A}-2 l$, P-1 $m(\mathrm{pu})-1 l / \mathrm{VI}: \quad \mathrm{A}-2 l, \quad \mathrm{P}-2 l / \mathrm{VII}: \quad \mathrm{D}-1 m\left(\mathrm{y}_{\mathrm{a}}\right)-$ $1 m-2 l$.

Rome's organ is very small, translucent, and shaped like the upper part of a ninepin.

Second antenna (A 2) (fig. 2B):

Pr: P-1l(pu)/Exo: $1 m(\mathrm{pu})-2 s / \mathrm{E} \quad \mathrm{I}: \quad \mathrm{In}-5 l(\mathrm{pu})-$ $1 s(\mathrm{pu}), \quad \mathrm{P}-\mathrm{Y}-1 m(\mathrm{pa}) / \mathrm{E}(\mathrm{II}+\mathrm{III}): \mathrm{A}-2 m(\mathrm{pu}), \mathrm{P}-$ $2 s\left(\mathrm{t}_{1}, \quad 4: \mathrm{pu}\right)-2 m\left(\mathrm{t}_{2}, \quad 3: \mathrm{pu}\right), \quad \mathrm{D}(\mathrm{P})-\mathrm{y}_{2}, \quad \mathrm{D}(\mathrm{Ex})-3 m$ $\left(\mathrm{z}_{1}, 2,3\right)-1 m\left(\mathrm{G}_{2}: 2 \mathrm{ser}\right), \mathrm{D}(\mathrm{In})-2 m\left(\mathrm{G}_{1,3}: 2 \mathrm{ser}\right) / \mathrm{E}$ IV: D-1s- $\mathrm{y}_{3}-1 s(\mathrm{pu})-1 s\left(\mathrm{G}_{\mathrm{m}}: \mathrm{ser}\right)-1 m\left(\mathrm{G}_{\mathrm{M}}: \mathrm{ser}\right)$. 

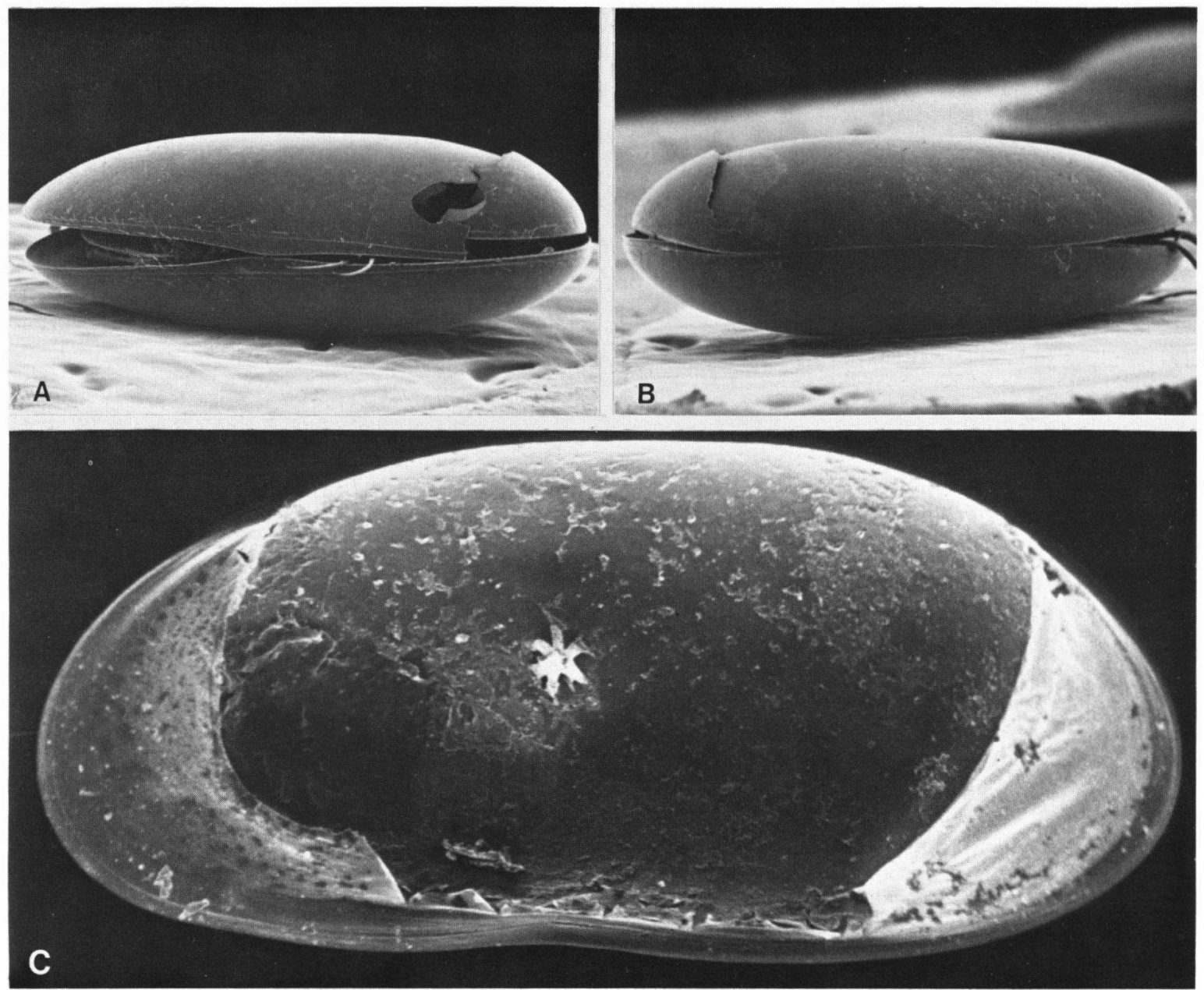

Fig. 1. Strandesia longula n. sp. (well near Gressier, Haiti, S 78/205-206; 9 paratypes): A-B, complete animal in ventral and dorsal view $(\times 51) ; \mathrm{C}$, right valve from inside $(\times 102)$.

The five long swimming bristles are 1.2 times the length of $G_{1}$ and $E(I I+I I I)$ together.

Mandibular palp (Mdp) (fig. 2E):

I: $\quad$ In-1s-2l( $\mathrm{S}_{1,}, 2$ :pu)- $\alpha / \mathrm{II}: \quad$ In-3l(pu)- $\beta(\mathrm{pu})-$ $1 m(\mathrm{pu}), \mathrm{Ex}-2 l(\mathrm{pl})-1 m(\mathrm{pl}) / \mathrm{III}: \mathrm{In}-1 m-1 s, \mathrm{Ex}-3 l-$ $1 m, \mathrm{~A}-3 m-\gamma(\mathrm{pa}) / \mathrm{IV}: \mathrm{D}-2 m$ (cs:ser) $-1 s(\mathrm{cs})-3 s$.

The nameless seta of segment $I$ is reduced to a very short one.

Maxillula (Mxu) (fig. 2D):

Mxup I: Ex-3m-3l/II: D-3s(cs)-3s/Mastic 1: In$2 s(\mathrm{pu}), \quad \mathrm{D}-12 s(\mathrm{cs}) / 2: \quad \mathrm{D}-8 \mathrm{~s}(\mathrm{cs}) / 3: \quad$ In- $1 s, \quad \mathrm{D}-$ $4 s(\mathrm{pu})-2 s(\mathrm{cs}: 2 \mathrm{ser})-2 s$.

The chelate setae of Mastic 3 are serrate at both sides.
Maxilla (Max) (fig. 2F):

Pr: A-2s(a), In-1s(b:pu)-1s(d:pu)/Exo: P$6 m(\mathrm{pu}) /$ Mastic: D-12s(pu)/E: D-2s(pu)-1m(pu). Two ' $a$ ' setae, one ' $b$ ' and one 'd' seta are present. The exopodite consists of six setae.

First thoracopod (T 1) (fig. 2H):

Pr: A- $1 s-1 m /$ E I: A-1s/E II: A-1m/E III: A-1s/E IV: D-2s-1l(G:ser).

All setae are plumose.

Second thoracopod (T 2) (fig. 2J):

Pr: In- $1 m, \mathbf{E x}-2 m / \mathbf{E}$ I: P-1 $m(\mathrm{pa}) / \mathrm{E}(\mathrm{II}+\mathrm{III})$ : P-1s(pa), D-Lo-pz 1 E IV: In-1 $m(\mathrm{pu})-\mathrm{CL}-\mathrm{pz}_{2}-$ $1 s$ (cs:2ser).

The distal part of E (II + III), and E IV, form 


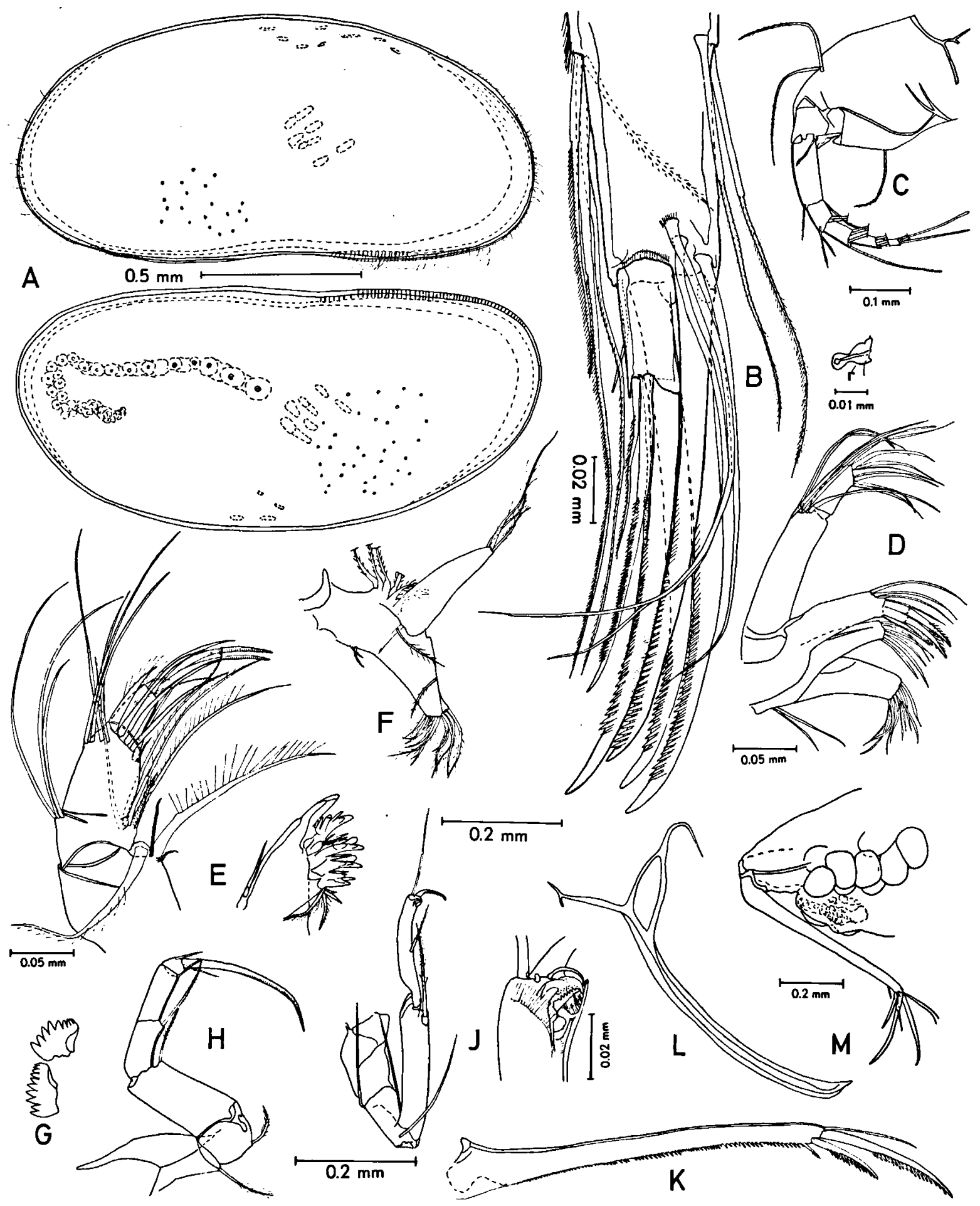

Fig. 2. Strandesia longula n. sp. (well near Gressier, Haiti, S 78/205-206; A-K, $९$ holotype; L, $९$ paratype): A, right and left valve from outside; B, detail of second antenna; C, antennule with Rome's organ (r); D, maxillula; E, mandibular palp with detail of mandible; F, maxilla; G, rake-like organs; H, first thoracopod; J, second thoracopod with detail of scratch foot; K, furca; L, furcal attachment; M, posterior part of body. 
the typical "pincer" complex as in most Cypridinae (fig. 2J, detail).

Furca (Fu) \& furcal attachment (Fuat) (figs. 2K-L):

The furca is strongly spinose along the greatest part of the posterior side. The distal claws are strongly spinose for 65 to $75 \%$ of their length. Seta $s_{p}$ is very short, carrying three small spines, and situated close to $G_{p}$. The anterior seta is smooth and much longer. Relative lengths of setae and claws are provided in table I. The furcal attachment has the dorsal Triebel's loop, characteristic of this genus. The loop is about as long as the ventral branch, and both are one-quarter of the length of the main branch.

Female copulatory organs (fig. 2M):

These have no special characters, they are situated relatively far to the front, leaving an open space between the proximal part of the furca and the distal part of the organs. Ovigerous females carry up to 25 eggs in the type-locality.

Etymology. - From the Latin longulus, meaning moderately elongated.

Taxonomic remarks. - All limbs have practically the same structure and chaetotaxy as the Antillean species of the genera Heterocypris and Hemicypris (Broodbakker, 1982, 1983a). The swimming bristles of A 2 are somewhat shorter, the furca has a much stronger armature, and a very short seta $s_{p}$ implanted close to the claw $G_{p}$, in contrast to the other two genera. Segment II of the maxillular palp is more elongated, one of the setae at the interior of segment I of the mandibular palp is reduced. The furcal attachment is totally different, as it is provided with a dorsal eyelet (Triebel's loop), in contrast to the other two genera.

There is some overall resemblance of $S$. longula to some of the species described by Sars (1901). However, after studying Sars's material, it became clear that $S$. longula and the other Caribbean species are not the same as the
Brazilian species described by Sars. S. tietensis and $S$. ovalis, two species which were very poorly described by Tressler (1949) from northern Brazil, have a carapace shape resembling that of $S$. longula, but their furcae are different. $S$. sudanica Sywula, 1969, from Sudan resembles $S$. longula in shape, but is much smaller and has another type of furca. Most other African and Asian species of Strandesia are fairly different from $S$. longula.

The ecology and distribution of this species will be discussed in part II of this paper.

\section{Strandesia botosaneanui n. sp.}

(Figs. 3, 4)

Material. - Holotype: one female (ZMA Ost. 150.837A). Allotype: one male (ZMA Ost. 150.837B). Paratypes: 3 dissected males, 4 dissected females, 1 undissected male and 3 undissected females.

Type-locality: B 69/10, Cuba, Cueva la Patana, in the village La Patana, Baracoa, Prov. Guantánamo, in the extreme east of Cuba $\left(20^{\circ} 11^{\prime} \mathrm{N} 74^{\circ} 08^{\prime} \mathrm{W}\right)$; in limestone of Miocene age; three levels, of which the lowest, the Cueva de los Bichos, was explored; distance from the sea less than $2 \mathrm{~km}$; altitude ca. $90 \mathrm{~m}$; the only water is in the "Galeria del Agua", which is $280 \mathrm{~m}$ long in western direction; numerous small to very large rimstone pools, of which some were dry, others containing water with a depth from 0.2 to $0.5 \mathrm{~m}$; bottom with black mud, containing much small fragments of charcoal, and many branches and pieces of wood; origin of water unknown, it could be the remnants of a temporary subterranean stream; 2-IV-1969; coll. L. Botosaneanu. Accompanying Ostracoda: Neocypridopsis inaudita (Furtos, 1936).

The species was only encountered in this station.

Geographical distribution known. - Cuba.

\section{Description}

Females as well as males have been found, in contrast to $S$. longula and $S$. cavernicola n. sp., which seem to be closely related to this species.

Relative lengths of segments and part of the setae of most appendages are given in table I.

Carapace (figs. 3A-C):

The carapace is smooth and whitish transparent. The specimens were, however, very decalcified. Valves sparsely hairy. Hinge adont. Muscle scars as typical of the Cypridinae. In dorsal view greatest width at the 

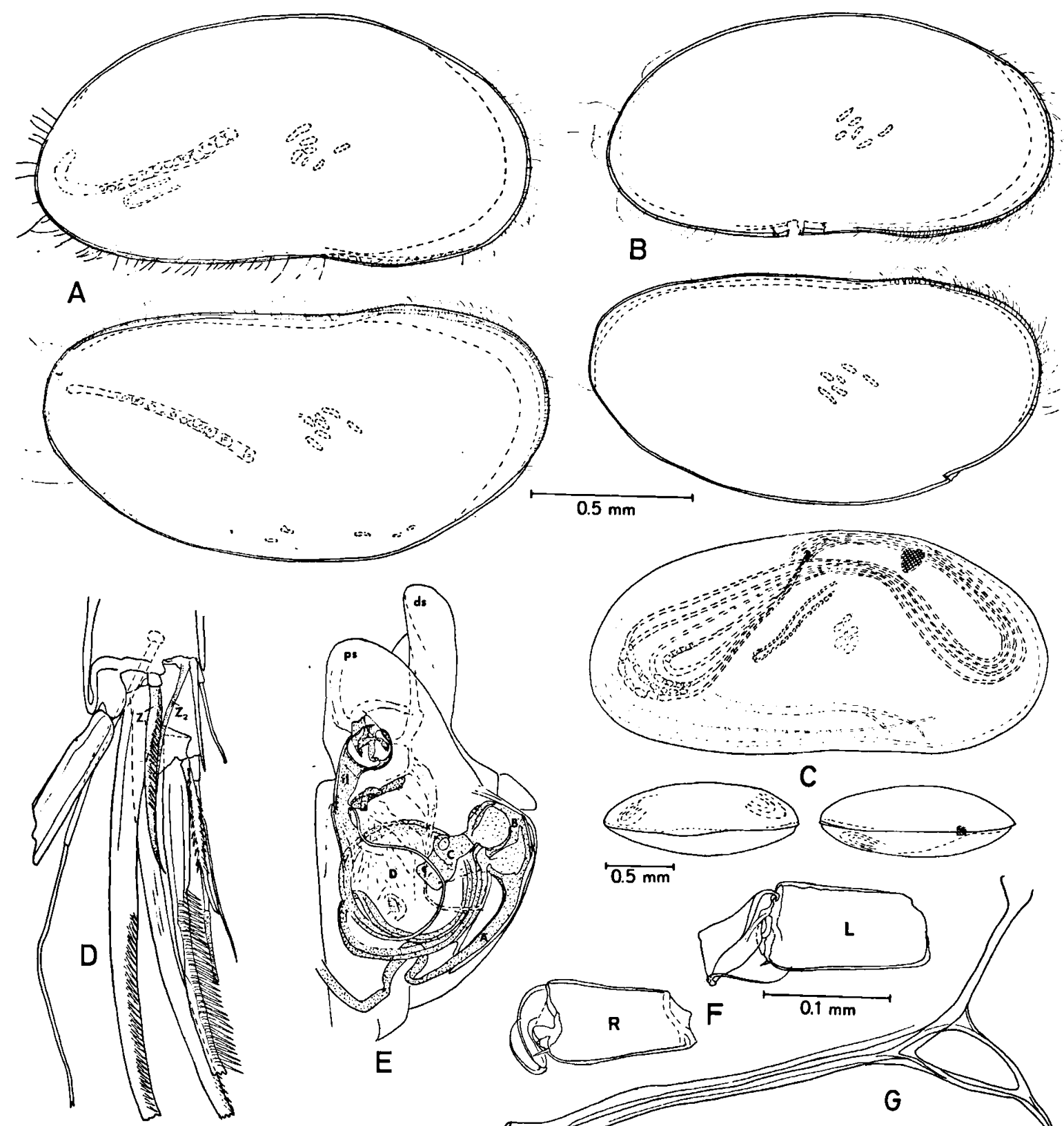

B

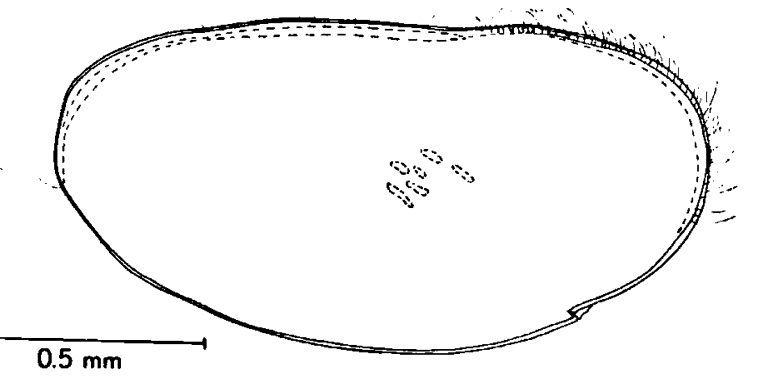


middle, being about $38 \%$ of the length. Greatest height at 35 to $55 \%$ of the length, being about $50 \%$ of the length. Left valve slightly larger than the right valve. The shape of the male and the female carapace is the same. Carapace moderately elongate, slightly less elongate than $S$. longula, but longer than $S$. cavernicola. The overall shape of the valves is very similar to that in $S$. longula, as are the marginal pore canals and other characters of the valves.

The four males measured ranged from 1.36 to $1.42 \mathrm{~mm}$ in length, and from 0.68 to 0.70 $\mathrm{mm}$ in height. The eight females measured ranged from 1.44 to $1.55 \mathrm{~mm}$ in length, and from 0.68 to $0.75 \mathrm{~mm}$ in height, mean length being: $1.50 \pm 0.045 \mathrm{~mm}$, and mean height: $0.72 \pm 0.025 \mathrm{~mm}$, which means that females are somewhat larger than males.

Antennule (A 1) (fig. 4A):

The chaetotaxy of this appendage is the same as in $S$. longula, only segment $\mathrm{V}$ is slightly longer.

Second antenna (A 2) (fig. 3D):

The female antenna has the same structure and chaetotaxy as in $S$. longula. Only $\mathrm{y}_{3}$ is relatively longer, and setae $t_{3}$ and $t_{4}$ do not seem to be plumose. In the male, the structure and chaetotaxy is up to E(II + III) the same, but the remaining part is different:

$\mathrm{E}(\mathrm{II}+\mathrm{III}): \quad \mathrm{A}-2 m(\mathrm{pu}), \quad \mathrm{P}-2 s\left(\mathrm{t}_{3}, 4\right)-1 s\left(\mathrm{t}_{1}: \mathrm{pu}\right)-1 m$ $\left(\mathrm{t}_{2}: \mathrm{pu}\right), \mathrm{D}(\mathrm{In})-1 s\left(\mathrm{z}_{1}: \mathrm{cs}: \mathrm{ser}\right)-1 s\left(\mathrm{z}_{2}\right)-1 m\left(\mathrm{G}_{1}: 2 \mathrm{ser}\right)$, $\mathrm{D}(\mathrm{P})-\mathrm{y}_{2}, \quad \mathrm{D}(\mathrm{Ex})-1 m\left(\mathrm{z}_{3}\right)-2 m\left(\mathrm{G}_{2}, \quad{ }_{3}: 2 \mathrm{ser}\right) / \mathrm{E} \quad \mathrm{IV}$ : $\mathrm{D}-2 s-\mathrm{y}_{3}-1 s\left(\mathrm{G}_{\mathrm{m}}: \mathrm{cs}: 2 \mathrm{ser}\right)-1 m\left(\mathrm{G}_{\mathrm{M}}: 2 \mathrm{ser}\right)$.

The chaetotaxy of the distal part of the male second antenna is thus of the same type as in the genus Heterocypris (Broodbakker, 1982). Seta $z_{1}$ is changed in a chelate serrate seta, and both $z_{1}$ and $z_{2}$ have moved to the interior side of the segment. $G_{M}$ is serrate with much longer spines than in the female, $G_{m}$ is shorter and chelate, but strongly serrate on two sides.

The structure and chaetotaxy of the mandibular palp (fig. 4D), maxillula, the first and second thoracopod (figs. 4B, E), and the furca and furcal attachment (figs. 3G, H), are the same as in $S$. longula. The female maxilla also has the same chaetotaxy. The male maxillar endopodites (fig. 3F) are transformed into claws, like in most Cyprididae, the left one being larger, with a triangularly shaped distal part, terminating in a flexible extended tip. The right one is smaller with a more slender distal part similarly ending in a long flexible tip. The shape of the claws is like that in other male Strandesia species, and has much in common with the shape of male maxillae in Heterocypris, in which genus the right one looks the same and the left one is less angulate, compared with Strandesia.

The furca and furcal attachment are of the $S$. longula type. The furca is bent slightly, in contrast to that of $S$. longula, which is almost straight.

\section{Copulatory organs (figs. 3C, E, 4F):}

The female copulatory organs have the same shape as in S. longula. The Zenker's organ in the male contains about 23 whorls of spines. The male has the characteristic coiling of the seminal vesicles in the anterior part of the valves.

Structure of the hemipenis: The proximal shield (ps) is triangularly shaped, with a rounded top. The distal shield (ds) is finger-like, likewise with a rounded top. Sleeves A, B and C of the labyrinth $\left(d_{1}, 2,3\right)$ are clearly visible. Sleeve D consists of some wide coils, which are clearly visible and terminate in a distal process surrounding the copulatory tube, with a few finger-like appendages. Like in other Cypridinae, there is a transversal fold on the medial side of the proximal shield. The proximal shield and sleeves A and B have the same structure as in the Heterocypris species from the West Indies (Broodbakker, 1982). The shape of the distal shield is different, and the coiled tubes of part $\mathrm{D}$ are more distinctly visible. A latch, as found in Heterocypris, is not really present, but some weakly sclerotized parts are visible, connecting the different parts and the proximal with the distal shield.

Etymology. - The species is named in honour of Dr. L. Botosaneanu, in recognition of his intensive biospeleological investigations in Cuba. 


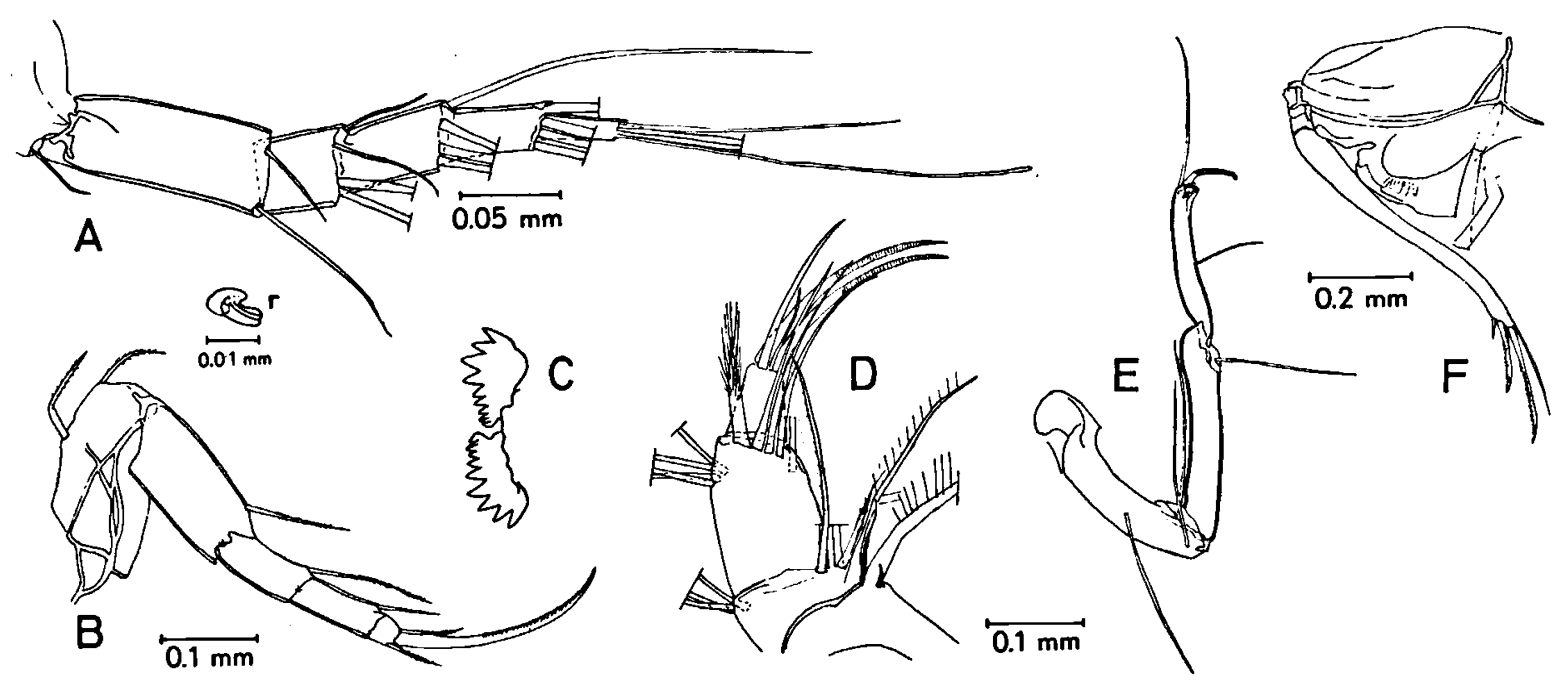

Fig. 4. Strandesia botosaneanui n. sp. (Cueva la Patana, Cuba, B 69/10; A-B, D-E, $\$$ holotype; C, F, $\$$ paratypes): A, antennule with Rome's organ (r); B, first thoracopod; C, rake-like organs; D, mandibular palp; E, second thoracopod; $\mathrm{F}$, posterior part of body.

Taxonomic remarks. - This species resembles $S$. longula in many aspects. The shape of the carapace is nearly the same, as are most of the appendages. Only the aesthetascs $y_{a}$ and $y_{3}$ are longer, which could be an indication of morphologic adaptation to cave-life. However, the species is oculated and there are no other indications of morphologic adaptation to subterranean life.

Ecology. - This species has been found in only one sample from Cuba. This sample was collected in cave pools, as indicated in the description of the type-locality. Therefore it is a hypogean species in the sense of Danielopol (1980), which means that the species will be supposed to be hypogean until evidence is found contradicting this supposition.

\section{Strandesia cavernicola $n$. sp.}

(Fig. 5)

Material. - Holotype: 1 female (ZMA Ost. 150.834A). Paratypes: 2 dissected females and about 100 undissected female specimens (ZMA Ost. 150.834B-C).

Type-locality: B 73/56, Cuba, Cueva Banega, situated near the village Mathias, between Baire and Charco Redondo, Sierra Maestra, Prov. Granma (named Prov. de Oriente until 1975$)\left(20^{\circ} 16^{\prime} \mathrm{N} 76^{\circ} 19^{\prime} \mathrm{W}\right)$; very shallow rimstone pools with much bat guano, water depth $3-4 \mathrm{~cm}$;
20-III-1973; coll. L. Botosaneanu. Accompanying fauna: Insecta.

Other stations: B 73/12, Cuba, Cueva de los Golondrinos, N. W. of Baracoa, Barrio Majana, Prov. Granma $\left(20^{\circ} 22^{\prime} \mathrm{N} 74^{\circ} 32^{\prime} \mathrm{W}\right)$; cave in the third marine terrace of coral limestone; small cave pools, some of them rimstone pools; total darkness; 21-II-1973; ca. 400 specimens; coll.

L. Botosaneanu.

B 73/45, Cuba, Cueva de la Virgen, in Siboney, Prov. Granma $\left(19^{\circ} 57^{\prime} \mathrm{N} 75^{\circ} 42^{\prime} \mathrm{W}\right)$; cave in the third marine terrace; cave pool with much guano; total darkness; 14-III-1973; 300 specimens. Accompanying fauna: Nematoda, Cyclopidae, Diptera larvae; coll. L. Botosaneanu.

Cuba, Cueva de Plumas, about $3 \mathrm{~km}$ N.E. of Matanzas, Prov. Matanzas $\left(23^{\circ} 05^{\prime} \mathrm{N} 82^{\circ} 35^{\prime} \mathrm{W}\right)$; cave pool near entrance; 14-XI-1970; ca. 160 specimens; coll. $\mathrm{T}$. Orghidan.

S 79/642, Haiti, Cave "Père La Ponce", not far from Roseaux, $300 \mathrm{~m}$ from the coast, Dépt. de Grande Anse $\left(18^{\circ} 35^{\prime} 42^{\prime \prime} \mathrm{N} 74^{\circ} 00^{\prime} 17^{\prime \prime} \mathrm{W}\right)$; some small, and one large rimstone pool, in the twilight; water depth $0.4 \mathrm{~m}$; chlorinity $120 \mathrm{mg} / \mathrm{l} ; 2-\mathrm{XII}-1979$; ca. 80 specimens. Accompanying fauna: Cladocera, Diptera larvae, Gastropoda.

Geographical distribution known. - Cuba, Haiti.

\section{Description}

Only females of this species have been found.

Relative lengths of segments and part of the setae of most appendages are given in table $I$. 
Carapace (figs. 5A, L):

The carapace is smooth, sparsely hairy, and yellowish transparent, probably because of conservation in formalin. Hinge adont. Muscle scars as typical of the Cypridinae. In dorsal view greatest width at the middle, being about $39 \%$ of the length. In lateral view greatest height at the middle, being 55 to $57 \%$ of the length. Left valve only slightly larger than the right valve. Carapace in lateral view suboval, being less elongate compared with $S$. longula. The overall shape of the carapace is, however, the same as in $S$. longula, the dorsal margin being slightly bent, and passing smoothly in the broadly rounded anterior and posterior margins. The ventral margin is only slightly sinuate with an anteroventral slight lip-like projection, which is somewhat stronger expressed in the left valve. Duplicature barely visible because of decalcification, but anteriorly broader than posteriorly. Selvage narrow in both valves. Marginal pore canals visible in the anteroventral part of the left valve, and the anterior and anteroventral part of the right valve. Flange slightly pronounced at the anteroventral part of the left valve.

The mean length of the carapace is $1.14 \pm$ $0.056 \mathrm{~mm}(n=58)$, with a length range of 1.03 to $1.26 \mathrm{~mm}$, in the type-locality. In the other stations in Cuba, the mean length ranges from 1.07 to $1.20 \mathrm{~mm}$, and the length of all specimens ranges from 1.01 to $1.28 \mathrm{~mm}$. The mean length of the specimens from Haiti (S $79 / 642)$ is $1.11 \pm 0.02 \mathrm{~mm}(n=38)$, with a total length range of 1.07 to $1.15 \mathrm{~mm}$, which is within the length range found in Cuba.

Antennule (A 1) (fig. 5B):

I: $\mathrm{A}-1 s(\mathrm{pu}), \quad \mathrm{P}-2 l(\mathrm{pu}) / \mathrm{II}: \mathrm{A}-1 s(\mathrm{pu}), \quad \mathrm{P}-\mathrm{r} / \mathrm{III}$ : $\mathrm{A}-1 s(\mathrm{pu}), \mathrm{P}-1 s(\mathrm{pu}) / \mathrm{IV}: \mathrm{A}-2 l, \mathrm{P}-2 s(\mathrm{pu}) / \mathrm{V}: \mathrm{A}-2 l$, P-1 $m(\mathrm{pu})-1 l / \mathrm{VI}: \quad \mathrm{A}-2 l, \quad \mathrm{P}-2 l / \mathrm{VII}: \quad \mathrm{D}-1 m\left(\mathrm{y}_{\mathrm{a}}\right)-$ $1 m-2 l$.

Rome's organ is very small, translucent and shaped as a short hollow tube.

Second antenna (A 2) (fig. 5C):

Pr: P-1 $m(\mathrm{pu}) /$ Exo: $1 m-2 s / \mathrm{E}$ I: In- $5 l-1 s, \mathrm{P}-\mathrm{Y}-$ $1 m(\mathrm{pl}) / \mathrm{E}(\mathrm{II}+\mathrm{III}): \quad$ A- $1 s-1 m, \quad$ P-1s(t 1 : 1 ser $)-$
$1 m\left(\mathrm{t}_{2}: 1 \operatorname{ser}\right)-1 m\left(\mathrm{t}_{3}\right)-1 s\left(\mathrm{t}_{4}\right), \quad \mathrm{D}(\mathrm{P})-1 s\left(\mathrm{y}_{2}\right), \quad \mathrm{D}(\mathrm{Ex})-$ $3 m\left(\mathrm{z}_{1,2,3}\right)-1 m\left(\mathrm{G}_{2}: 2 \mathrm{ser}\right), \mathrm{D}(\mathrm{In})-2 m\left(\mathrm{G}_{1,3}: 2 \mathrm{ser}\right) / \mathrm{E}$ IV: D-1s-y $y_{3}-1 s\left(\mathrm{G}_{\mathrm{M}}\right.$ :ser $)-1 s\left(\mathrm{G}_{\mathrm{m}}\right.$ :cs:2ser $)$.

The chaetotaxy of $\mathrm{A} 2$ is the same as in $S$. longula, only the length and structure of part of the setae is different. The swimming bristles are very short, being $97 \%$ of the length of $\mathrm{E}(\mathrm{II}+\mathrm{III})$ and $\mathrm{G}_{1}$ together; the short swimming bristle is $33 \%$ of the length of E I (table I). Setae $t_{3}$ and $t_{4}$ seem to be smooth, while $t_{1}$ and $t_{2}$ are serrate at one side.

Mandibular palp (Mdp) (fig. 5D):

The chaetotaxy is the same as in $S$. longula. The nameless seta of the first segment is likewise reduced. Only seta $\gamma$ is longer, being 1.3 times the length of the third segment.

The chaetotaxy of the maxillula (fig. 5E), maxilla, first and second thoracopod (figs. $5 F-G$ ), and furca (fig. $5 \mathrm{~J}$ ), is the same as in $S$. longula. The furca is strongly serrate, especially the claws, the spines of the ramus are less strong compared with $S$. longula. The posterior seta is plumose. The furcal attachment is comparable with that of $S$. longula. The ventral branch is longer than the loop.

Female copulatory organs (fig. 5K):

The female copulatory organ is situated more posteriorly than in $S$. longula, protruding slightly beyond the distal part of the body. The female carries about 16 eggs.

Etymology. - The species is named "cavernicola" because it was only encountered in caves, in Cuba as well as in Haiti.

Taxonomic remarks. - The species resembles $S$. longula as well as $S$. botosaneanui, but it is less elongate and less tumid. The furca and furcal attachment are also of the same type as found in both other species. The terminal claw of the first thoracopod is shorter, the claws and segment $\mathrm{E}(\mathrm{II}+\mathrm{III})$ of the second antenna are shorter, compared with segment $E \mathrm{I}$, and the aesthetascs $y_{a}, Y$ and $y_{3}$ are longer. The swimming bristles of the second antenna are comparatively short as well (table II). Like in $S$. 


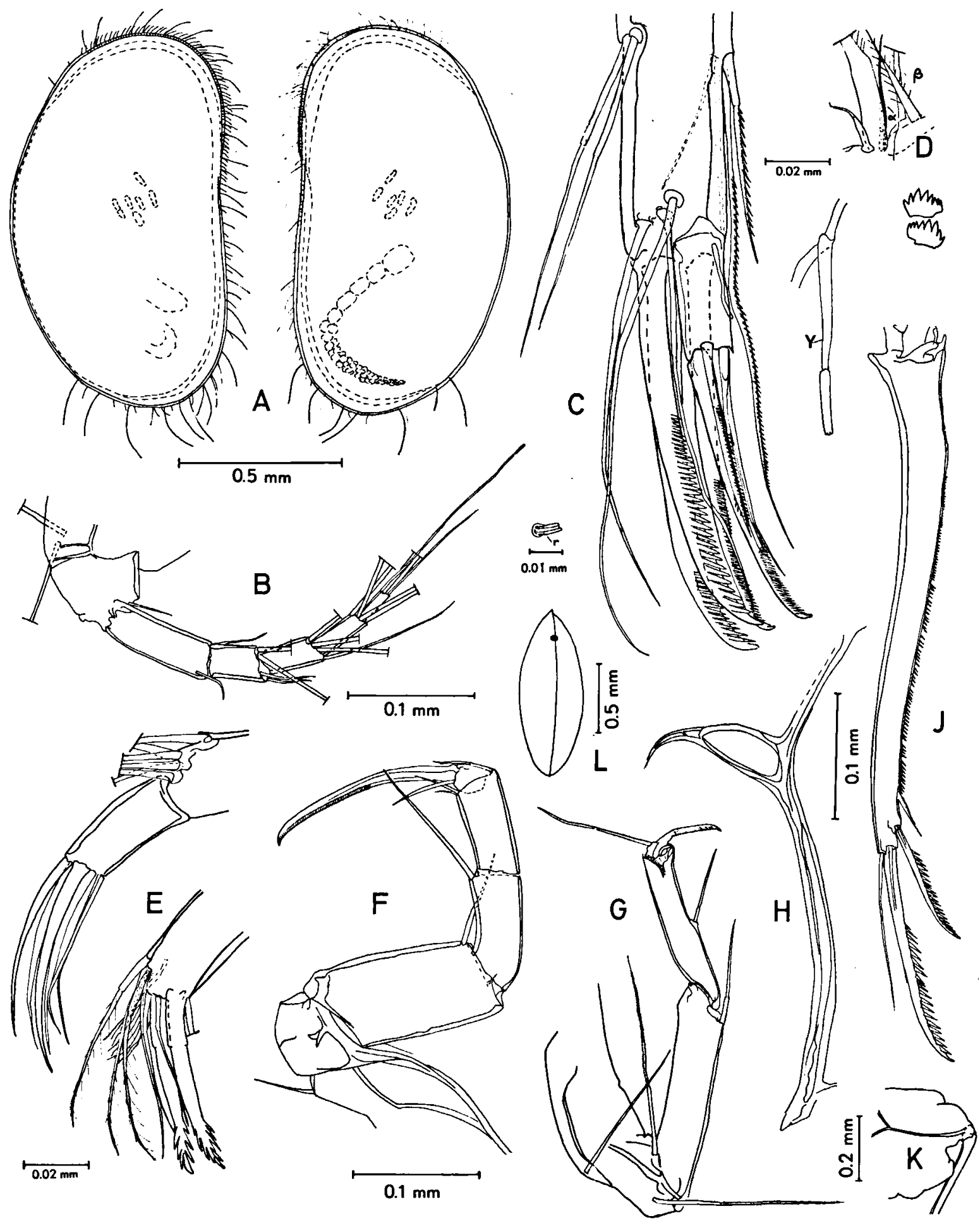

Fig. 5. Strandesia cavernicola n. sp. (Cueva Banega, Cuba, B 73/56; A, D-G, J, ९ holotype; B-C, H, ९ paratype): A, right and left valve from outside; B, antennule with Rome's organ ( $\mathrm{r}$; C, second antenna with aesthetasc $\mathrm{Y}$; D, detail of mandibular palp, and rake-like organs; E, maxillula; F, first thoracopod; G, second thoracopod; H, furcal attachment; J, furca; $\mathrm{K}$, posterior part of body; L, carapace in dorsal view. 
botosaneanui, these characteristics could mean some form of preadaptation to the subterranean environment.

Ecology. - The species was found in considerable numbers in cave pools in four caves of Cuba, of which three in the Provincia Granma, and the fourth in the Provincia Matanzas. Furthermore, it was found in a cave near the coast of the most western part of Haiti, near Jérémie. It was encountered in smaller and larger cave pools, often with much guano and in darkness. It was never accompanied by other species of Ostracoda.

The species is oculated, but the eye is much smaller than, for instance, in $S$. longula. Therefore the species is supposed to be hypogean until further evidence proves the contrary. The fact that it is found in Cuba as well as in Haiti can be explained by a land bridge which probably has existed between these two islands in the Miocene or late Pliocene (Hedges, 1982).

\section{Strandesia stocki n. sp.}

(Figs. 6, 7D-G)

Material. - Holotype: one female (ZMA Ost. 150.829A). Paratypes: 11 dissected and about 400 undissected female specimens (ZMA Ost. 150.829B-C).

Type-locality: S 79/568, Haiti, Dépt. du Sud-Est, well at the extreme $W$. of the village Marigot, about $10 \mathrm{~m}$ from the littoral $\left(18^{\circ} 13^{\prime} 51^{\prime \prime} \mathrm{N} 72^{\circ} 19^{\prime} 43^{\prime \prime} \mathrm{W}\right)$; water table at 2.5 $\mathrm{m}$, water depth $0.4 \mathrm{~m}$; chlorinity $62 \mathrm{mg} / \mathrm{l}$; Cuetkov net; 16-XI-1979. Accompanying fauna: Oligochaeta, Cyclopidae, Insecta. Accompanying Ostracoda: Strandesia longula n. sp., Stenocypris major (Baird, 1859), Cypretta sp.

Other stations: Haiti: many stations, which will be described in part II of this paper: S 78/199 to 201, 205, $206,215,231,234$ to $237,239,240$. S 79/529, 536, 541, $560,566,568,591,592,597,599,647,677$ to 682,688 . Stations on other islands:

Cuba, Rio San Vicente, near Vinales, in Sierra de los Organos, Prov. Pinar del Rio; 6-VI-1969; 15 specimens; coll. St. Negrea. Accompanying Ostracoda: Strandesia longula, Pseudocandona antilliana Broodbakker, 1983c, Cypridopsis sp.

Cuba, Ariguanobo; 4-XII-1970; ca. 50 specimens; coll. T. Orghidan. Accompanying Ostracoda: Strandesia longula, Cypretta sp., Cypridopsis aff. vidua, Physocypria sp., Stenocypris major.

S 82/105, Jamaica, St. Mary, Brave River, near Fontabelle; altitude $\pm 85 \mathrm{~m}\left(18^{\circ} 21^{\prime} 41^{\prime \prime} \mathrm{N} 76^{\circ} 57^{\prime} 20^{\prime \prime} \mathrm{W}\right)$; lateral springs in riverbank, fine gravel, sand, clay; slowly running; roots; 18-III-1982; 3 specimens. Accompanying fauna: Cyclopidae, Gastropoda, Insecta; Cypretta sp., Pseudocandona antilliana.

S 78/154, St. John (Virgin Islands, U.S.A.), Adrian Well, road above Cruz Bay ("Center Line Road") $\left(18^{\circ} 20^{\prime} 40^{\prime \prime} \mathrm{N} 64^{\circ} 45^{\prime} 57^{\prime \prime} \mathrm{W}\right)$; old open well; diameter $3 \mathrm{~m}$; chlorinity $310 \mathrm{mg} / \mathrm{l} ; 27-\mathrm{IV}-1978 ; 40$ specimens. Accompanying fauna: Cyclopidae, Gastropoda.

St. Martin, reared from dried mud from Slob of Welgelegen, near Philipsburg; III-1983; coll. J. J. Jongsma. Other reared Ostracoda: Strandesia longula, Stenocypris major. Neocypridopsis debilis Klie, 1940, Physocypria affinis.

WH 098, St. Martin, rock pool of Mornes Rouges, Terres Basses; water hole in volcanic rock; dimensions: $2 \times$ $1.5 \times 1 \mathrm{~m}$; chlorinity $70 \mathrm{mg} / \mathrm{l} ; 23-\mathrm{VI}-1973 ; 2$ specimens.

WH 503, St. Kitts, Wingfield River, $300 \mathrm{~m}$ N. of bridge of main road; slowly flowing, narrowly connected pools, with cascades up to $30 \mathrm{~cm}$; natural, permanent rivulet on volcanic rock and semicultivated soil; clear; dimensions: (3 x) 1 × $0.3 \mathrm{~m}$; chlorinity $35 \mathrm{mg} / \mathrm{l} ; 30$-VI-1949; 2 specimens.

WH 847, Dominica, Portsmouth River, at bridge, slowly flowing streamlet, almost without pools, few algae; chlorinity $80 \mathrm{mg} / \mathrm{l}$; 5-VII-1967; 2 specimens. Accompanying fauna: Decapoda, Gastropoda, Heteroptera; Cypridopsis sp. (Ostracoda).

WH 770, Martinique, Ruisseau de la Pagerie, TroisIlets, near ruins of mill; largest pool in rather rapidly flowing semipermanent streamlet; on andesite and semicultivated soil; rocky substrate; few algae; chlorinity $210 \mathrm{mg} / \mathrm{l} ;$ 10-II-1964: 12 specimens. Accompanying Ostracoda: Cypridopsis aff. vidua.

Geographical distribution known. - Cuba, Jamaica, Haiti, St. John (U.S. Virgin Islands), St. Martin, St. Kitts, Dominica, Martinique.

\section{Description}

Only females of this species have been found. It is therefore supposed to be parthenogenetic.

Relative lengths of some setae and segments of most appendages are given in table I.

Carapace (figs. 6A, E, 7D-G):

The carapace is punctate, with shallow pits (fig. $7 \mathrm{E}$ ), sparsely hairy, except for the anteroventral margin which is strongly hairy (figs. 6A, 7F). Hinge adont. Muscle scars as typical of Cypridinae. Colour pinkish transparent, probably because of preservation in formalin. In dorsal view greatest width at about the middle, being 50 to $55 \%$ of the length. In lateral view 
greatest height at the middle, being 58 to $60 \%$ of the length. Carapace tumid, in lateral view subreniform. Left valve overlapping right valve, especially ventrally and anteriorly. Dorsal margin broadly rounded, passing smoothly in the also broadly rounded anterior and posterior margins. Ventral margin more or less straight, with anteriorly a lip-like projection, which is stronger in the right valve. Duplicature wider anteriorly than posteriorly, which is best visible in figs. 7D, G. Marginal pore canals only distinct in the lip-like projection of the right valve, and slightly visible in the anterior and anteroventral part of the left valve. Selvage broader in the left valve, especially anteriorly. Flange visible at the ventral margin.

The mean length of the left valve is $0.80 \pm$ $0.01 \mathrm{~mm}(n=9)$, and of the right valve $0.77 \pm$ $0.01 \mathrm{~mm}(n=9)$, in the type-locality. The mean height of the left and right valves is 0.46 $\pm 0.01 \mathrm{~mm}(n=9)$. The mean length of undissected females in the type-locality is $0.79 \pm$ $0.015 \mathrm{~mm}(n=45)$, the length range being 0.76 to $0.82 \mathrm{~mm}$. In the other localities in Haiti mean lengths ranged from 0.77 to $0.91 \mathrm{~mm}$. The few animals sampled on other islands also fall within this length range.

Antennule (A 1) (fig. 6D):

I: A-1s, P-2l(pu)/II: A-1s, P-r/III: A- $1 s(\mathrm{pa})$, P-1s/IV: A-2l, P-1s-1s(pa)/V: A-2l, P-1m$1 l / \mathrm{VI}: \mathrm{A}-2 l, \mathrm{P}-2 l / \mathrm{VII}: \mathrm{D}-1 m-1 m\left(\mathrm{y}_{\mathrm{a}}\right)-2 l$.

Rome's organ is small, translucent, and looks like a bent hollow tube.

Second antenna (A 2):

Pr: P-1l/Exo: 1l-2s/E I: In-5l(pu)-1s, P-Y$1 m(\mathrm{pa}) / \mathrm{E}(\mathrm{II}+\mathrm{III}): \quad \mathrm{A}-2 m, \quad \mathrm{P}-1 s\left(\mathrm{t}_{1}\right)-1 m\left(\mathrm{t}_{4}: \mathrm{pu}\right)-$ $2 l\left(\mathrm{t}_{2,3}: \mathrm{pu}\right), \mathrm{D}(\mathrm{P})-\mathrm{y}_{2}, \mathrm{D}(\mathrm{Ex})-3 m\left(\mathrm{z}_{1}, 2,3\right)-1 m\left(\mathrm{G}_{2}\right.$ : 2 ser $), \mathrm{D}(\mathrm{In})-2 m\left(\mathrm{G}_{1,3}\right.$ :ser $) / \mathrm{E}$ IV: D-1s( $\left.\mathrm{y}_{3}\right)-2 s$ ?$2 m\left(\mathrm{G}_{\mathrm{M}, \mathrm{m}}\right.$ :ser $)$.

The chaetotaxy of A 2 is practically the same as in $S$. longula. The distal claws are relatively longer than in $S$. longula, and hooked at their tops.

Mandibular palp (fig. 6B):

I: $\quad$ In-1 $l-2 m\left(\mathrm{~S}_{1,2}: \mathrm{pu}\right)-1 m(\alpha) / \mathrm{II}: \quad$ In-2m(pu)-
$2 l(\mathrm{pu})-1 s(\beta: \mathrm{pu}), \mathrm{Ex}-1 s-2 l / \mathrm{III}: \mathrm{In}-1 m-1 s, \mathrm{Ex}-1 s-$ $3 m, \mathrm{~A}-1 s(\gamma: \mathrm{pu})-3 m / \mathrm{IV}: \mathrm{D}-2 m$ (cs:ser)-2m-2s.

The structure and chaetotaxy are the same as in $S$. longula, except for the nameless seta of the first segment, which is not reduced, and setae $\alpha$ and $\beta$ which are longer (table I).

The chaetotaxy of the maxillula (fig. 6F), maxilla and the first and second thoracopod (figs. 6G-H), is the same as in S. longula.

Furca \& furcal attachment (figs. $6 \mathrm{~K}, \mathrm{~J}$ ):

The furca is clearly different from that in $S$. longula. The armature is not as strong, the claws and posterior seta are relatively longer, and the furcal ramus is more slender, as compared to $S$. longula.

The dorsal loop of the furcal attachment is more triangular and shorter than in S. longula, while the main branch seems to be thicker. The ramus of the furca is finely serrate for most of its length, as is the posterior seta. The furcal claws are serrate for 65 to $75 \%$ of their length.

Female copulatory organs (fig. $6 \mathrm{~J}$ ):

More posterior than in $S$. longula, protruding somewhat distally. No other special characteristics.

Etymology. - The species is named in honour of Prof. Dr. J. H. Stock, the coordinator of the Amsterdam Expeditions to the West Indian Islands, and of my research project concerning the Ostracoda of the West Indies.

Taxonomic remarks. - $S$. stocki belongs to the smaller, more globular species of Strandesia, with a finely serrate furca, and slender claws. This group will be called the stocki group. Some species described by Sars (1901) seem to have affinities with $S$. stocki. Study of these species proves them to be related, but not identical. $S$. intrepida and $S$. nec obtusata described by Furtos (1936) from Yucatan seem to be related, but are much larger. $S$. stocki has much in common with most species described by Rome from Zaire and Lake Tanganyika (Rome, 1962, 1964). Most of these species are, however, larger than $1 \mathrm{~mm}$ and distinctly asymmetrical. The only species of 

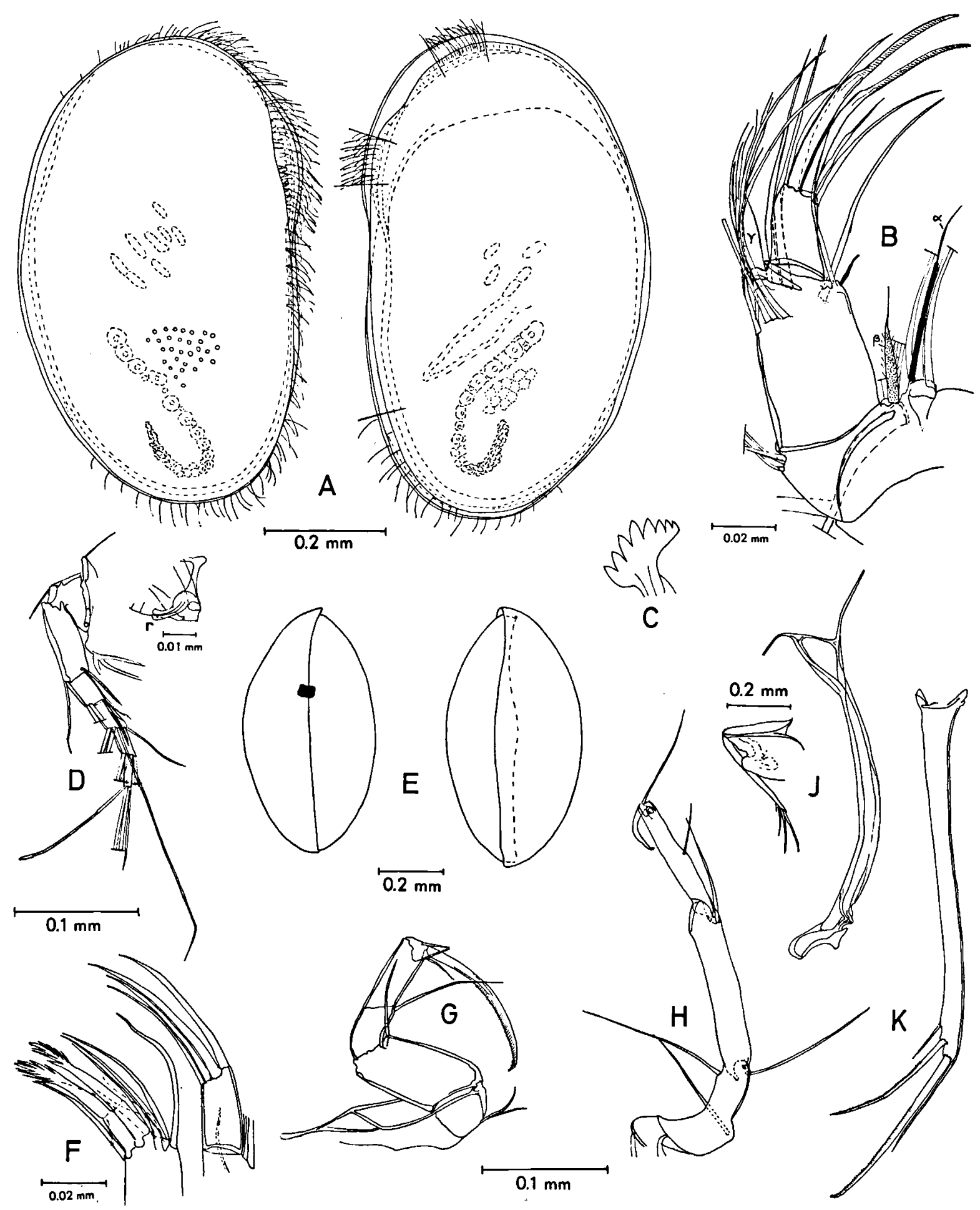

Fig. 6. Strandesia stocki n. sp. (well near Marigot, Haiti, S 79/568; A-C, F-H, ९ holotype; D-E, J-K, ९ paratypes): A, right and left valve from outside; B, mandibular palp; C, rake-like organ; D, antennule with Rome's organ (r); E, carapace in dorsal and ventral view; F, maxillula; $\mathrm{G}-\mathrm{H}$, first and second thoracopod; J, posterior part of body and furcal attachment; $K$, furca. 
the same size is $S$. anterotundata, which strikingly resembles $S$. stocki, these species being probably very closely related. Another species from Africa which seems to have affinities with $S$. stocki is $S$. unicolor, which is, however, larger. In Asia, $S$. vittata and $S$. decorata seem to have the most affinity with $S$. stocki and with the species described next. $S$. vittata is larger and more like $S$. sphaeroidea n. sp., while $S$. decorata is about as small as $S$. stocki, but more triangular in shape. Of the Indian species described by Hartmann (1964), S. rotunda seems to be the closest relative. The European species Cypricercus obliquus has the same shape and surface structure as $S$. stocki. Likewise, the appendages very much resemble those of $S$. stocki, but $C$. obliquus is much larger.

$S$. stocki seems to be a species with close relatives in all parts of the world. It belongs to a type which is probably the most widespread of all Strandesia s.l. species.

Strandesia sphaeroidea $n$. sp.

(Figs. 7A-C, 8)

Material. - Holotype: one female (ZMA Ost. 150.826A). Paratypes: 4 dissected females and 19 undissected females (ZMA Ost. 150.826B-C).

Type-locality: WH 752, Marie-Galante, Rivière du Vieux Fort, Vangout, near a road crossing; in swampy area some $50 \mathrm{~m}$ wide; limestone debris, muddy; crowded with grasses, Cyperaceae, Chara, Eichhornia, and a few Acrostichum; chlorinity $1165 \mathrm{mg} / \mathrm{l} ; 31-\mathrm{I}-1964$. Accompanied by one specimen of Perissocytheridea sp. (Ostracoda).

Other stations: WH 755A, Marie-Galante, Marais de Folle Anse, S. of Saint-Louis, swamp of several ha connected with open water in swamp forest of several $\mathrm{km}^{2}$; very muddy; crowded with Chara, fields of Eichhornia, some Acrostichum; chlorinity $330 \mathrm{mg} / \mathrm{l} ; 31-\mathrm{I}-1964 ; 16$ specimens. Accompanying Ostracoda: Chlamydotheca unispinosa, Cypris subglobosa Sowerby, 1840, Tanycypris meridana (Furtos, 1936), Strandesia trispinosa galantis $\mathbf{n}$. subsp.

WH 756A, Marie-Galante, Rivière de Saint-Louis, 100 $\mathrm{m}$ upstream of Les Sources; very muddy pool; dimensions: $5 \times 2 \times 0.5 \mathrm{~m}$; some Chara; chlorinity about $50 \mathrm{mg} / \mathrm{l}$; 1-II-1964; 2 specimens. Accompanying Ostracoda: Cypris subglobosa, Tanycypris meridana.

S 78/44, Antigua, John Hughes Well, Parish of St. Mary, S. of road ( = Mill Hill); round, diam. $2 \mathrm{~m}$, largely covered, clean well; chlorinity $920 \mathrm{mg} / \mathrm{l}$; 13-IV-1978. Accompanying fauna: Cyclopidae, Pyrgophorus (Gastropoda). Accompanying Ostracoda: Physocypria affinis Klie, 1933, Pseudocandona antilliana.
Geographical distribution known. - MarieGalante, Antigua.

\section{Description}

Only females of this species have been found.

Relative lengths of some setae and segments of most appendages are given in table I.

\section{Carapace (figs. 7A-C, 8A):}

The carapace is punctate with shallow holes, as in S. stocki (fig. 7C), sparsely hairy, except for the anteroventral region, which is moderately hairy (fig. 8A). Hinge adont. Muscle scars as typical of the Cypridinae. Colour whitish (because of conservation in formalin), with irregular blue-green patches. Carapace in dorsal view tumid, greatest width just behind the middle, being nearly $60 \%$ of the length. In lateral view ovoid, boldly arched, greatest height just in front of the middle, being nearly $60 \%$ of the length. Dorsal margin rounded, the top being slightly angular (about $140^{\circ}$ ), especially in the right valve. Left valve overlapping right valve, especially ventrally. Both anterior and posterior margins broadly rounded. The ventral margin of the right valve is slightly sinuate with a small lip-like projection anteroventrally. The ventral margin of the left valve is slightly convex, the selvage being comparatively wide ventrally and anteriorly. Marginal pore canals are visible anteriorly, and very short ones posteriorly in the left valve. In the right valve they are clearly visible anteroventrally, and anteriorly somewhat more to the inside. Duplicature anteriorly much wider than posteriorly. The valves are clearly unequal, which gives the carapace a twisted appearance, when seen from the anterior or posterior side. Flange inconspicuous.

The mean length of the carapaces in the typelocality is $1.33 \pm 0.03 \mathrm{~mm}(n=24)$, the length range being 1.28 to $1.39 \mathrm{~mm}$. In station WH $755 \mathrm{~A}$ the mean length is $1.30 \pm 0.06 \mathrm{~mm}(n=$ $16)$, and the length range is 1.22 to $1.39 \mathrm{~mm}$. The four specimens sampled on Antigua were small, ranging in length from 1.23 to $1.27 \mathrm{~mm}$. 


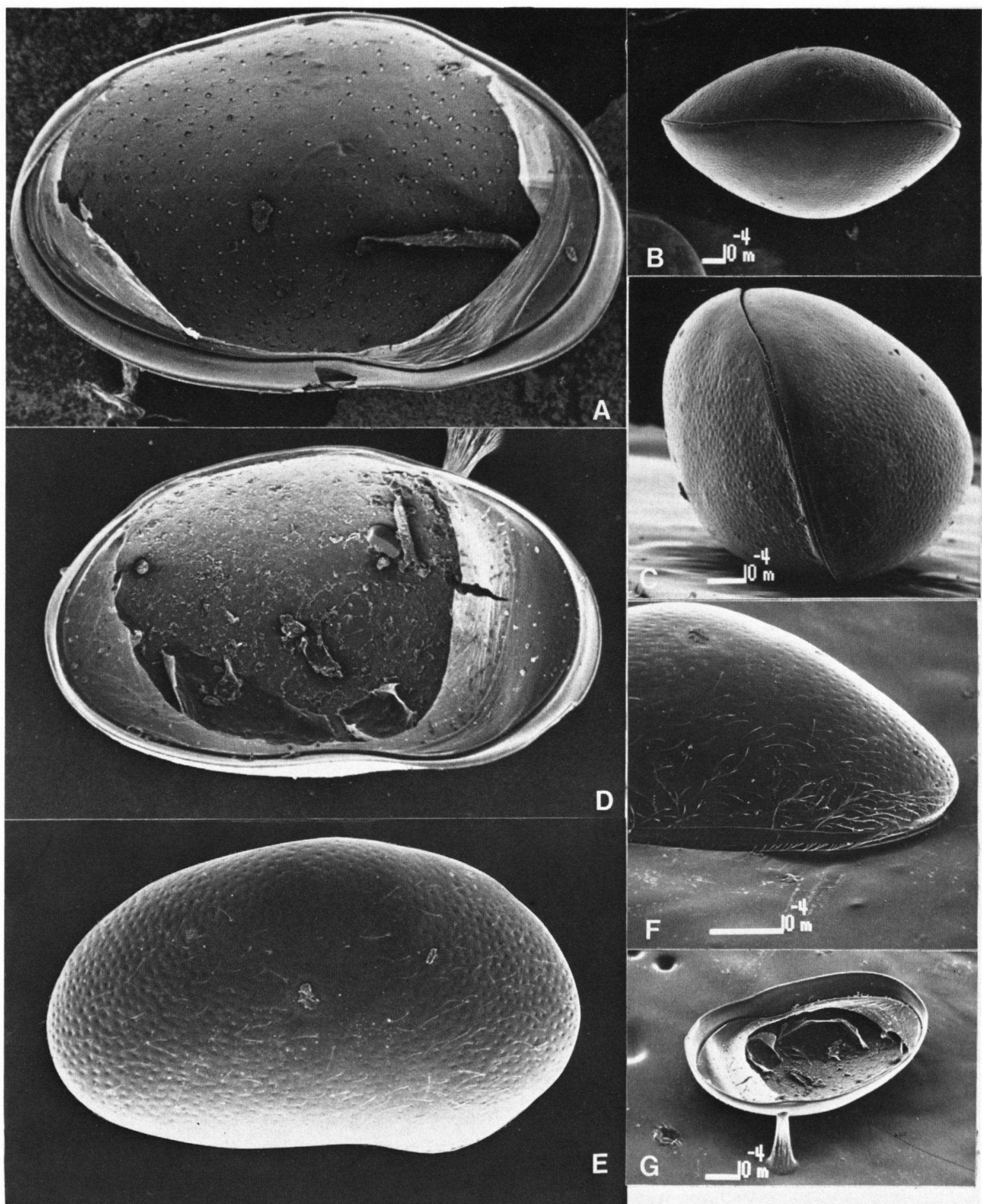

Fig. 7. A-C, Strandesia sphaeroidea n. sp. (Rivière du Vieux Fort, Marie-Galante, WH 752; \& paratypes); D-G, Strandesia stocki $n$. sp. (well near Marigot, Haiti, S 79/568; \& paratypes): A, left valve from inside ( $\times$ 74); B-C, carapace in ventral and anterior view; D, left valve from inside ( $\times 123)$; , right valve from outside $(\times 123)$; , anteroventral part of the right valve; $G$, inner structures of the left valve. 
Antennule (A 1) (fig. 8B):

The chaetotaxy is the same as in the other species, but of the three short anterior bristles of segment III to $\mathrm{V}$, the first two are longer, and the third is shorter than in the other species. The bristles are strong and plumose. Aesthetasc $\mathrm{y}_{\mathrm{a}}$ is very short. Rome's organ is a short straight hollow tube.

Second antenna (A 2):

Chaetotaxy as in $S$. stocki. The terminal claws are hooked at the tips. The long swimming setae are plumose and more than twice the length of $E I$, the exopodal setae are short, $G_{m}$ is straight and slender. The proportional lengths of segments and claws are the same as in $S$. stocki.

Mandibular palp (Mdp) (fig. 8C):

Chaetotaxy the same as in $S$. stocki, the nameless seta of the first segment is long. The two longest distal chelate setae are plumose instead of serrate, unlike those in $S$. stocki.

The chaetotaxy of the maxillula (fig. 8D), maxilla, and the first and second thoracopod (figs. 8E-F), is the same as in the other species. The chelate setae of the second segment of the maxillular palp and of the third masticatory process are relatively long, as in $S$. stocki, probably because the second segment of the maxillular palp is shorter than in the species of Strandesia with a more elongate carapace. The relative lengths of the segments and setae of the first and second thoracopod are about the same as in $S$. stocki. The distal claw of the first thoracopod is even longer.

Furca \& furcal attachment (figs. 8H, G):

The furca is less slender than in $S$. stocki. The posterior seta is longer than in the other species and finely serrate. Claws and ramus are serrate as in $S$. stocki. The anterior seta is smooth and long. The furcal attachment is stout and wide.

Female copulatory organs (fig. 8J):

These organs resemble those in $S$. stocki.
Etymology. - The species is named "sphaeroidea" because of the tumid shape of the carapace.

Taxonomic remarks. - S. sphaeroidea clearly belongs to the $S$. stocki group, having long antennal claws, long swimming bristles as compared with E I, and slender, finely serrate furcal claws. Furthermore, the first segment and claw of the first thoracopod are comparatively long, and the chelate setae of the second segment of the maxillular palp and the third masticatory process are long. However, the carapace is much larger, and distinctly more asymmetric than in $S$. stocki. In general it looks like most species discussed after the description of $S$. stocki, but it seems to be closest to $S$. vittata. In this species the valve surface is likewise pitted, with shallow holes, but it is larger. Another distinctly asymmetric species is $S$. asymmetros from Lake Tanganyika, which is smaller and less tumid. Klie (1940) described S. obliqua, another asymmetric species, from northeastern Brazil. According to his drawings, the species is differently shaped and less tumid. It is only slightly smaller than $S$. sphaeroidea, but it could be the same species. Since Cypricercus obliquus has to be placed in Strandesia, which will be proven in the sequel, $S$. obliqua Klie becomes the junior homonym of the European species. Thus, either the name of this species has to be changed, or it must be attributed to $S$. sphaeroidea.

Ecology. - The species was encountered only in a few samples from two islands lying not so far apart. It was found at chlorinities ranging from 330 to $1165 \mathrm{mg} / \mathrm{l}$. On Marie-Galante it was found in very muddy pools, twice in a swampy area with much vegetation, and once near a rivulet. It was found together twice with Tanycypris meridana, a species formerly described as Strandesia meridana, by Furtos (1936). This species clearly belongs to the genus Tanycypris, which is closely related to Strandesia. Strandesia trispinosa galantis $\mathrm{n}$. subsp. was also found in one of the three stations. 


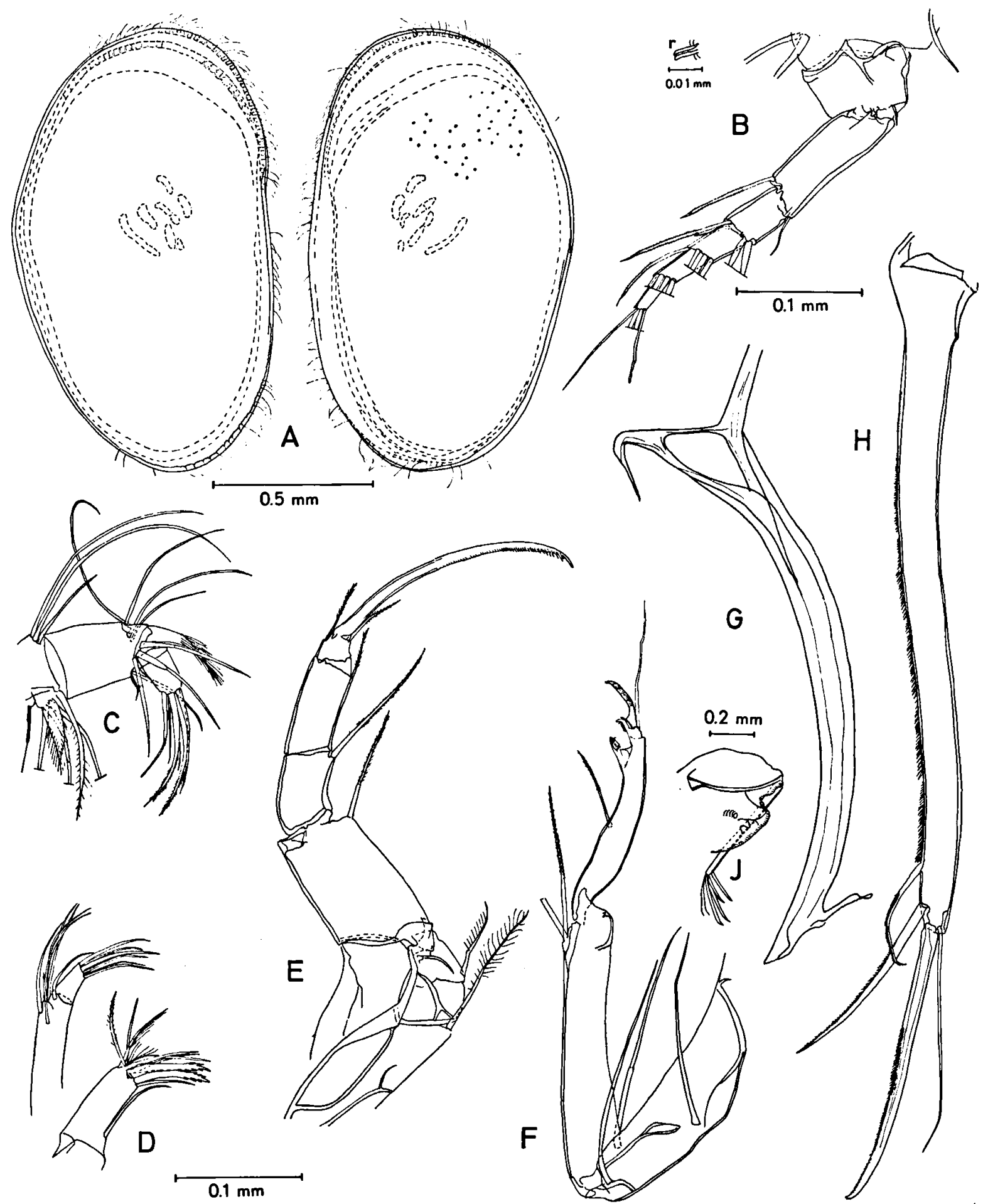

Fig. 8. Strandesia sphaeroidea $\mathrm{n}$. sp. (Rivière du Vieux Fort, Marie-Galante, WH 752; $\$$ holotype): A, right and left valve from outside; B, antennule with Rome's organ (r); C, mandibular palp; D, maxillula; E-F, first and second thoracopod; G, furcal attachment; $\mathrm{H}$, furca; J, posterior part of body. 
On Antigua the species was found in a largely covered, clean well, a habitat contrasting with the habitats on Marie-Galante. Considering the type of habitats in which it was found on Marie-Galante, it is supposed to be epigean.

Strandesia trispinosa galantis n. subsp.

(Fig. 9)

Material. - Holotype: one female (ZMA Ost. 150.841A). Paratype: one female (ZMA Ost. 150.841.B). Type-locality: WH 755A, Marie-Galante, Marais de Folle Anse, S. of Saint-Louis, swamp of several ha, connected with open water in swamp forest of several $\mathrm{km}^{2}$; very muddy; crowded with Chara, field of Eichhornia, some Acrostichum; chlorinity $330 \mathrm{mg} / \mathrm{l} ; 31-\mathrm{I}-1964$. Accompanying Ostracoda: Chlamydotheca unispinosa, Tanycypris meridana, Strandesia sphaeroidea, Cypris subglobosa.

Only two female specimens of this subspecies have been found.

Geographical distribution known. - MarieGalante.

\section{Description}

Carapace (figs. 9A-B):

The shape of the carapace, the duplicature, selvage, the dorsal hump, and the marginal tubercles of the right valve, are the same as in Strandesia trispinosa (Pinto \& Purper, 1965) from Brazil. The anterior spines of the left valve are slightly larger, and the posterior spine of the right valve is much larger.

The two specimens from Marie-Galante measure: holotype: L-valve: $1.09 \times 0.62 \mathrm{~mm}$, $R$-valve: $1.03 \times 0.65 \mathrm{~mm}$; paratype: L-valve: $1.05 \times 0.60 \mathrm{~mm}, \mathrm{R}$-valve: $0.97 \times 0.62 \mathrm{~mm}$. The posterior spines of the right valves measure 0.38 and $0.36 \mathrm{~mm}$, respectively. The carapaces are measured without the spines. The mean length of the specimens from Brazil is 1.095 $\mathrm{mm}$, which means that the specimens from Marie-Galante have the same size. The height of the specimens from Marie-Galante is 57 to $64 \%$ of the length, while in the specimen pictured by Pinto \& Purper (1965) it is 63 to $67 \%$ of the length.

The appendages are practically the same as in the species described from Brazil. Therefore on- ly differences with the other subspecies will be mentioned.

Antennule (A 1):

Chaetotaxy as in $S$. stocki, only aesthetasc $y_{\mathbf{a}}$ much shorter.

Second antenna (A 2):

Chaetotaxy as in $S$. stocki, long and slender claws, hooked at the tops. In contrast to the other Strandesia species, the three exopodal setae are all short.

Mandibular palp (Mdp) (fig. 9D):

Of the same type as in $S$. stocki. Part of the setae is somewhat longer, $\boldsymbol{\gamma}$ is very long and pappose distally. One of the chelate setae of segment IV is wider than the others, with a blade-like plumose distal part. The two other chelate setae are smaller and smooth.

Maxillula (Mxu) (fig. 9E):

Chaetotaxy as in $S$. stocki; however, one of the chelate setae of Mxup II, and the two serrate chelate setae of Mastic 3, have blade-like serrate tips, as in the large chelate seta of the mandibular palp.

The chaetotaxy of the maxilla and the first and second thoracopod is the same as in the other species. The proportional lengths of the segments of the first thoracopod are about the same as in $S$. sphaeroidea, but the terminal claw is relatively longer than in the other species.

Furca (Fu) (fig. 9G):

The furca is very elongate and slender, even more than in the other species of the stocki group. The claws are very delicate and finely serrate for three-quarters of their length. The ramus is also slender and elongate and finely serrate for most of its length.

Furcal attachment (Fuat) (fig. 9C):

Likewise delicate, with a long ventral branch, being 3.3 times as long as the dorsal eyelet, which is more oval than in the other species of Strandesia and closely resembles that of Cypricercus (Bradleycypris) affinis (Fischer, 1851), as can 

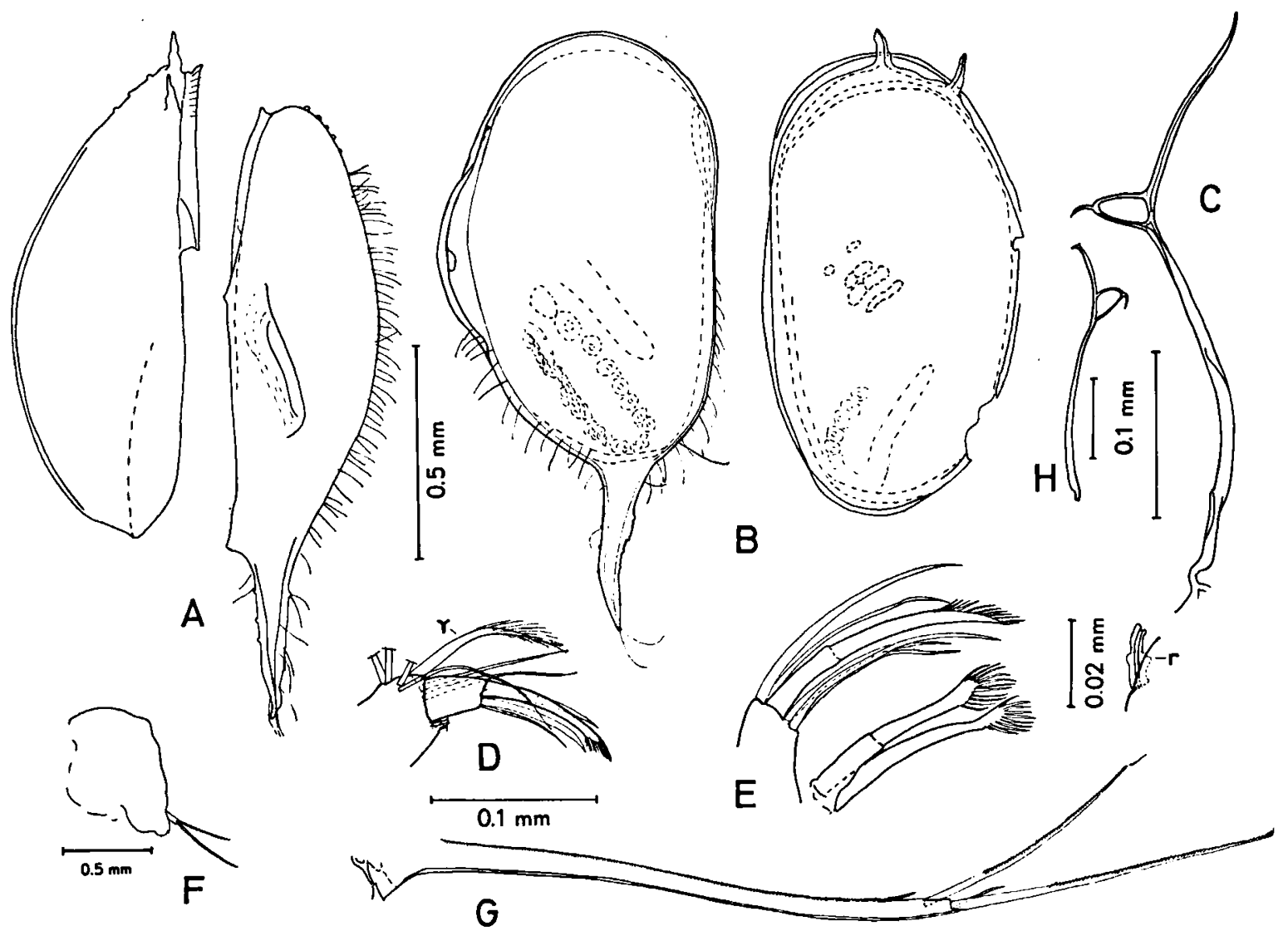

Fig. 9. A-G, Strandesia trispinosa galantis n. subsp. (Marais de Folle Anse, Marie-Galante, WH 755A; $\$$ holotype); H, Strandesia weberi (Moniez, 1892) (Celebes, Indonesia; $\&$ paralectotype): A, valves in dorsal view; B, valves in lateral view; C, H, furcal attachments; D, detail of mandibular palp; E, maxillula and Rome's organ (r); F, posterior part of body; G, furca.

be seen in Rome (1969: 182, fig. 7). In the other Cypricercus (Bradleycypris) species from Europe and North America, the distal part of the eyelet is more rounded and formed at a short distance from the medial shaft (McKenzie, 1982; Rome, 1969).

Female copulatory organs (fig. 9F):

The organs seem to bulk out over the furca, as shown in fig. 9F. The internal structure is not clear.

Etymology. - The name "galantis" is derived from the island name Marie-Galante.

Taxonomic remarks. - S. trispinosa (Pinto \& Purper, 1965) was considered to be a Cyprinotus species by the authors, because of the dorsal gibbosity. McKenzie (1971a) already pointed out that the species probably did not belong to Cyprinotus. Victor \& Fernando (1981a) correctly placed it in the genus Strandesia, because of the presence of Triebel's loop (dorsal eyelet) in the furcal attachment. McKenzie (1982) placed it in Strandesia as well, because of the eyelet and the flexuous furca. He also stressed that some Strandesia species likewise have a right valve gibbosity (like $S$. bicuspis bicuspis (Claus, 1892), $S$. mercatorum Vávra, 1895, and the next described species).

Victor \& Fernando (1981a), in redescribing $S$. weberi (Moniez, 1892), discovered the great resemblance between this species and $S$. trispinosa. In the Asian species $S$. weberi there 
seems to be a considerable variation in length of the anterior and posterior spines. Specimens from Malaysia have much longer spines than those from the Philippines. The specimens of $S$. trispinosa from Marie-Galante likewise have considerably longer anterior and especially posterior spines than the specimens from southern Brazil sampled by Pinto \& Purper (1965). Furthermore, the dorsal gibbosity seems to be smaller, and probably therefore the carapace has a lesser relative height. The morphology of the appendages seems to be the same in both forms. Because of these differences and the geographical distance between the known populations of Marie-Galante and southern Brazil, I decided to divide the species in two subspecies, $S$. trispinosa trispinosa from Brazil, and $S$. trispinosa galantis from Marie-Galante.

In addition to the absence of the dorsal gibbosity in $S$. weberi, as compared with both subspecies of $S$. trispinosa, there are more differences. Investigation of a paralectotype of $S$. weberi revealed that this species does not possess the blade-like tips on the chelate setae of the Mdp, Mxup II, and Mastic 3, and that the furcal attachment is different from that in $S$. trispinosa (fig. $9 \mathrm{H}$ ).

There are no other species of Strandesia known with two anterior spines and one posterior spine, but there are some species with a posterior spine. These are: $S$. mucronata (Sars, 1901) from Itatiba in southern Brazil, also described by Von Daday (1905) from Paraguay, and by Méhes (1913) from Colombia, which has a short stout spine at the posterior side of the right valve. Brehm (1934) described this species from Surinam, but in his drawing of a juvenile he shows two anterior spines on the left valve and one posterior long spine on the right valve, exactly the same as in S. trispinosa galantis. Tressler (1949) recorded Cypricercus episphaena Müller, 1908, from São Paulo, Brazil, which is not far from Itatiba; this species is most probably closely related to $S$. mucronata, and not identical with Cypricercus episphaena, a species living in South Africa. Müller (1912) changed the name mucronata in acanthigera, which was unnecessary and not ac- cepted by Méhes and Von Daday (Méhes, 1913).

The other species with a posterior spine on the right valve is $S$. centrura Klie, 1940, from northeast Brazil.

Ecology. - S. trispinosa trispinosa has been found in a muddy sandy pool under trees, and in the muddy sandy border of a channel connecting two lakes. One of the stations was in grassland and the other between grassland and a swampy area. S. trispinosa galantis was found in the same type of muddy habitat, in a swampy area with many grasses, with water of low chlorinity $(330 \mathrm{mg} / \mathrm{l})$.

Strandesia pistrix n. sp.

(Figs. 10, 11)

Material. - Holotype: one female (ZMA Ost. 150.842A). Allotype: one male (ZMA Ost. 150.842B). Paratype: one undissected female (ZMA Ost. 150.842C). Type locality: S 79/508, Haiti, Dépt. du Sud-Est, large karst spring with many water outlets in front of the "Bar de Simon', along the road from Cayes to Camp-Perrin

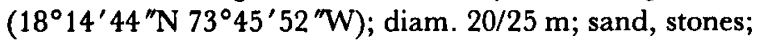
submerged vegetation; water clear; chlorinity $25 \mathrm{mg} / 1$; 1-XI-1979. Accompanying fauna: Tricladida, Hirudinea, Oligochaeta, Hyalella (Amphipoda), 1 hadziid amphipod, Insecta, Gastropoda, fishes; 1 male Cypris sp. (Ostracoda).

Only three specimens of this species were found.

\section{Description}

Relative lengths of some setae and segments of most appendages are given in table $I$.

Carapace (figs. 10A-E):

The surface is smooth, but very finely and densely punctate, sparsely hairy, and whitish transparent, which could be due to conservation in formalin. Hinge adont, muscle scars as typical of Cypridinae, but elongate. In dorsal view greatest width just in front of the middle, being $46 \%$ of the length. In lateral view greatest height in front of the middle, just in front of the dorsal tuberculation, at 35 to $38 \%$ of the length, being $55 \%$ of the length. Left valve larger than right valve. Carapace ovally rounded, in lateral view more or less ovate, in dorsal view elongate elliptical. The dorsal margin of 

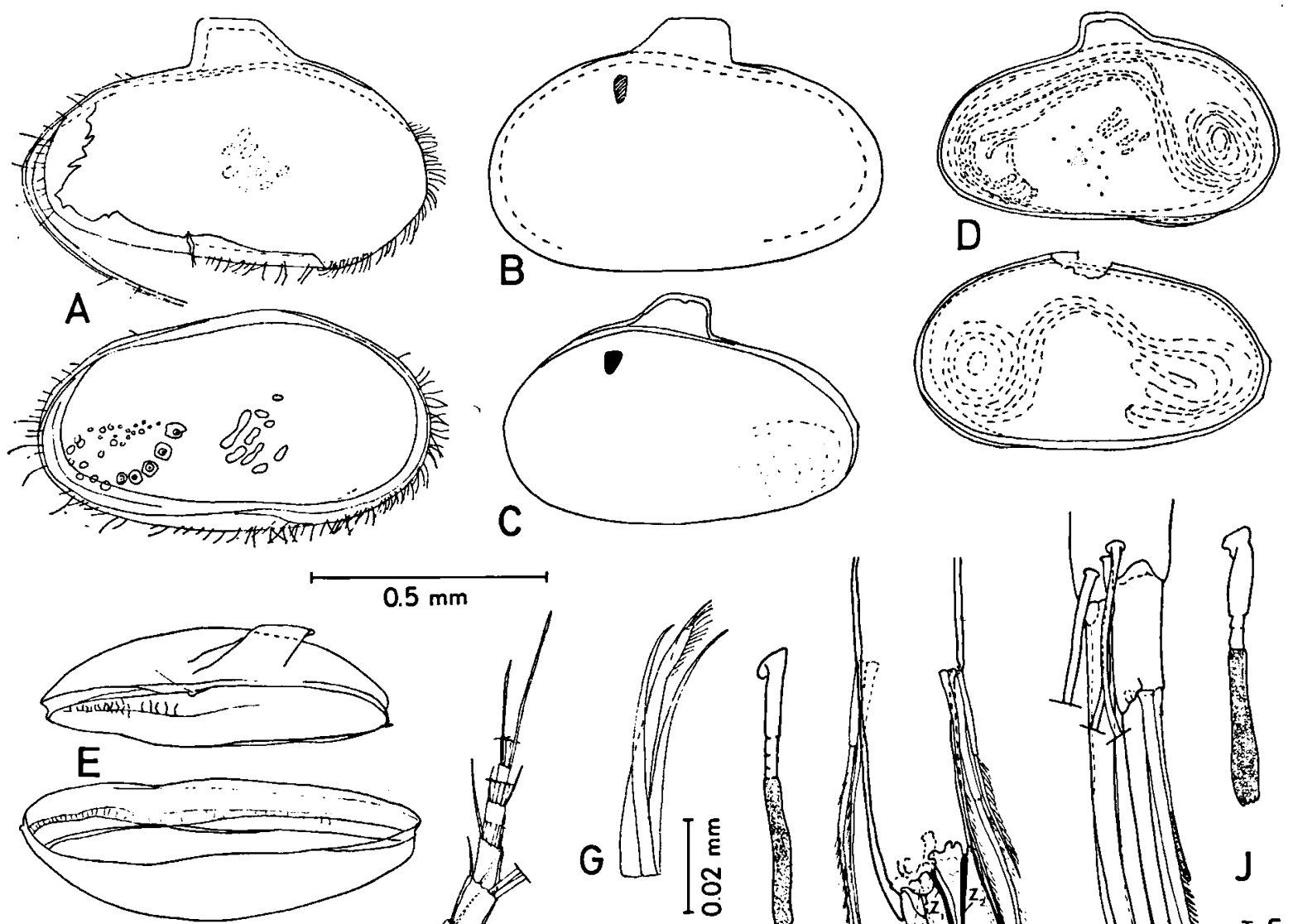

$0.5 \mathrm{~mm}$

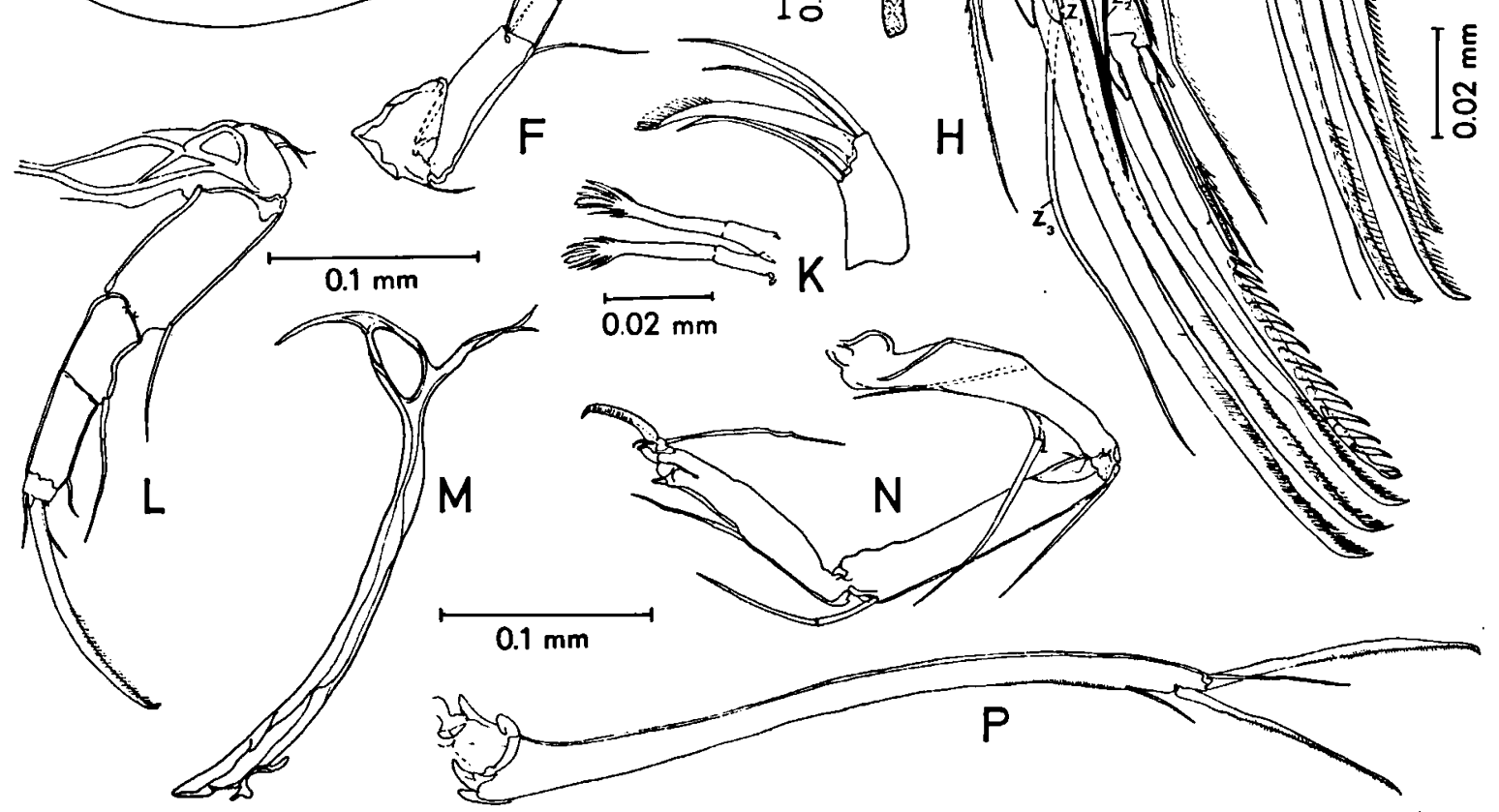

Fig. 10. Strandesia pistrix n. sp. (well near Cayes, Haiti, S 79/508; A-B, E-G, J, L-P, $९$ holotype; C-D, H, K, O allotype): A, right valve from outside, and left valve from inside; $B, C$, undissected specimens; $D$, right and left valve from outside; E, valves in dorsal view; F, antennule; G, chelate setae of segment IV of the mandibular palp; H, J, details of second antennae with aesthetascs $\mathrm{Y}$; $\mathrm{K}$, chelate setae of the maxillular palp and third masticatory process; L, first thoracopod; $M$, furcal attachment; $N$, second thoracopod; $P$, furca. 
both valves is straight and slightly declining at the posterior side, and short and more rounded at the anterior side. The dorsal angle is about $150^{\circ}$. The dorsal margin passes smoothly in both anterior and posterior margins. The ventral margin of the left valve is slightly convex, the selvage being comparatively wide ventrally and posteriorly. The ventral margin in the right valve is almost straight with anteroventrally a lip-like projection. Marginal pore canals and duplicature are very inconspicuous, probably because of decalcification. Flange likewise inconspicuous.

The right valve bears a very characteristic dorsal tuberculation, which is fin-shaped, it is as in S. trispinosa, but stronger and higher.

The shape of male and female carapace is practically the same, but the male is smaller. The left valve of the male measures $0.77 \times 0.42$ $\mathrm{mm}$, and the right valve $0.74 \times 0.41 \mathrm{~mm}$. The two female carapaces measure both $0.85 \times$ 0.47-0.48 mm; valves could not be measured.

Antennule (A 1) (fig. 10F):

Structure and chaetotaxy as in $S$. stocki, only the first segment is relatively longer.

Second antenna (A 2) (figs. 10H-J):

The female antenna is as in $S$. stocki, with long and slender claws, hooked at the tops. Aesthetasc $\mathrm{Y}$ is longer, and the longest seta of the exopodite is shorter.

Likewise, the male antenna has long and slender claws, which are finely serrate, except for $G_{M}$, which is strongly serrate, and $G_{m}$, which is reduced, as in the male of $S$. botosaneanui. The serration of $\mathrm{G}_{\mathrm{M}}$ in males of $S$. stocki is, however, even stronger developed. Setae $z_{1}$ and $z_{2}$ have moved to the interior side of the segment, while $z_{1}$ is transformed into a short smooth chelate seta. Seta $z_{2}$ is short, and seta $z_{3}$ is of medium length.

\section{Mandibular palp (Mdp):}

Structure and chaetotaxy as in $S$. stocki, but one of the distal chelate setae of segment IV has a blade-like serrate projection, and the other two are smooth, as in S. trispinosa (fig. 10G.).
Maxillula (Mxu):

Structure and chaetotaxy as in S. trispinosa, with blade-like, serrate, chelate setae on Mxup II and Mastic 3 (fig. 10K).

\section{Maxilla (Max) (fig. 11A):}

The female maxillae are like those in the other species. The right male maxilla has a curved slender distal claw, with a short flexible tip. The endopodite itself is more or less rectangular, as is the endopodite of the left maxilla, which possesses, however, a rounded obtrusion. The distal claw of the left maxilla is oval with an anterior rounded indentation, and a short flexible tip.

Thoracopods 1 and 2 (T1 and T2) (figs. 10L, N):

The thoracopods have the same chaetotaxy and structure as in $S$. stocki.

Furca \& furcal attachment (Fu \& Fuat) (figs. 10P, M):

The furca is finely serrate, as are the claws and posterior seta. The ramus is less slender than in $S$. trispinosa, but more slender than in the other species described in this paper. Claw $G_{a}$ is relatively short, compared with the ramus, and $G_{p}$ is nearly as long as $G_{a}$. The relative length of the setae is the same as in $S$. stocki. The furcal attachment is slender, with a short eyelet and a ventral branch of medium length.

\section{Copulatory organs (figs. 11B-D):}

The structure of the female copulatory organ is unclear, the posterior part is blunt, without special characters. The Zenker's organ of the male contains 15 whorls of spines. The male has the coiling of the seminal vesicles in the anterior parts of the valves, which is characteristic of the Cypricercini. The proximal shield of the hemipenis (ps) has a rounded top, the distal shield (ds) is boot-like and pointed. Sleeves A, $B$, and $C$ of the labyrinth are the same as in $S$. botosaneanui. Part $\mathrm{D}$ consists of three coils, which are less wide than in $S$. botosaneanui, and comparable with the coils found in the Antillean species of the genus Heterocypris. The copulatory 

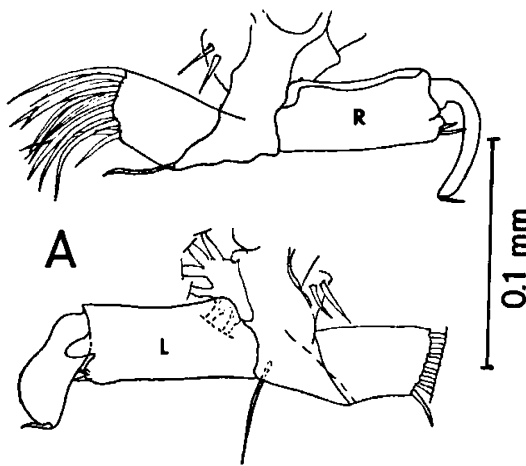
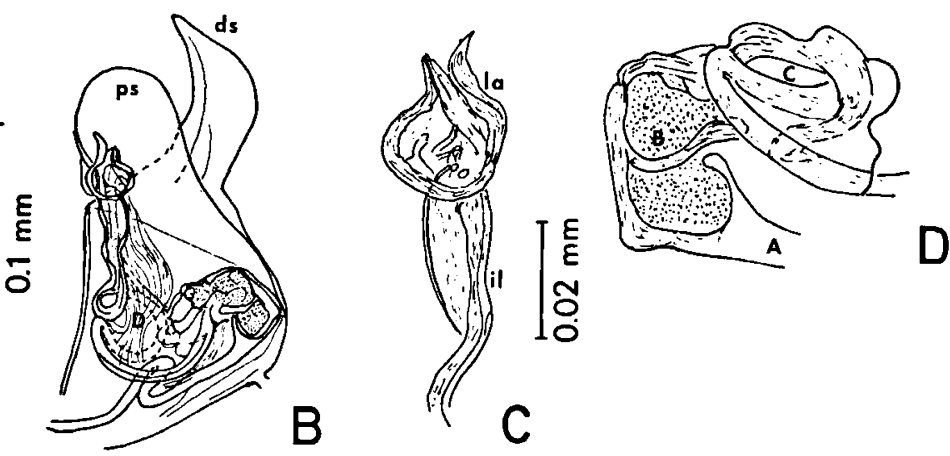

Fig. 11. Strandesia pistrix n. sp. (well near Cayes, Haiti, S 79/508; O allotype): A, right and left maxillae; B, hemipenis (ps, ds = proximal and distal shields, $\mathrm{D}=$ part $\mathrm{D}$ of the labyrinth); $\mathrm{C}$, inner lobe (il) with distal parts (la = latch) of hemipenis; D, sleeves $\mathrm{A}, \mathrm{B}$, and $\mathrm{C}$ of the labyrinth.

tube is surrounded by the inner lobe (il), which terminates in some distal processes, of which one, the latch (la) seems to be a broadly curved structure, acuminate at both ends. The distal parts of the inner lobe and the coils in part $D$ are connected by fibrous parts.

Etymology. - From the Latin pistrix, meaning shark. The species is thus named because of the fin-like dorsal protuberance, which looks like the dorsal fin of a shark.

Taxonomic remarks. - The chelate setae of the mandibular palp and the maxillula are serrate in the same way as in $S$. trispinosa, which also has a small dorsal projection. The furca is, however, not as long and slender, and the furcal attachment is stronger with the eyelet less rectangularly positioned on the median shaft. $S$. bicuspis has a much longer dorsal ala and a longula-type of furca. S. feuerborni from Sumatra and $S$. hancocki from Uganda have different dorsal alae and furthermore anterior lip-like projections. $S$. cyprinotoides from Zaire and $S$. strandesiodes from Madagascar have other types of alae as well.

$S$. pistrix seems to be intermediary between Bradleycypris-like species as $S$. trispinosa, and Strandesia species of the stocki group.

Ecology. - The species is oculate, but has a relatively long aesthetasc $\mathrm{Y}$. It was found in a large, open, karstic spring with water of low chlorinity, and much vegetation. Therefore it is considered to be epigean. Since only 3 specimens were found, in only one sample, not much can be said about the ecology of the species.

\section{Strandesia venezolana $n$. sp.}

(Fig. 12)

Material. - Holotype: 1 female (ZMA Ost. 150.839A). Allotype: 1 male (ZMA Ost. 150.839B). Paratypes: 5 males and 5 females dissected and about 400 undissected specimens.

Type-locality: S 82/509, Venezuela, Mayorquines, Peninsula de Morocoy, Estado Falcon; one of several coenotes about $50 \mathrm{~m}$ from the littoral $\left(10^{\circ} 53^{\prime} 29^{\prime \prime} \mathrm{N} 68^{\circ} 14^{\prime} 46^{\prime \prime} \mathrm{W}\right)$; water table at $3 \mathrm{~m}$, water depth $4 \mathrm{~m}$; diam. about $2-3 \mathrm{~m}$; incomplete darkess; soft bottom with much vegetal matter; Cvetkov net; chlorinity $460 \mathrm{mg} / \mathrm{l}$; 1-III-1983. Accompanying fauna: Oligochaeta, Insecta, Gastropoda.

Other stations: All in Venezuela, most samples containing the species were from the Peninsula de Morocoy, where many coenotes and some horizontal caves were investigated, and also some sources.

S $82 / 500$, source transformed in well at "La Luisa", at the base of a limestone wall, next to the road $\left(10^{\circ} 52^{\prime} 03^{\prime \prime} \mathrm{N} 68^{\circ} 19^{\prime} 27^{\prime \prime} \mathrm{W}\right)$; dimensions: $4.5 \times 1.5 \mathrm{~m}$, water depth $0.5 \mathrm{~m}$; Cvetkov net; chlorinity $145 \mathrm{mg} / \mathrm{l}$; 28-II-1982; about 70 specimens. Accompanying fauna: Tricladida, Cyclopidae, Anura larvae; Ostracoda: Cypretta sp., Darwinula sp., Candonopsis hummelincki Broodbakker, 1983 c.

S 82/501, karst spring at Lizardo $\left(10^{\circ} 52^{\prime} 03^{\prime \prime} \mathrm{N}\right.$ $\left.68^{\circ} 15^{\prime} 50^{\prime \prime} \mathrm{W}\right)$; water catched in large cemented container, covered with a concrete plate with a rectangular opening; water depth $0.5 \mathrm{~m}$; bottom muddy; water clear and clean; 
chlorinity $190 \mathrm{mg} / \mathrm{l} ; 28-\mathrm{II}-1982 ; 1$ specimen. Accompanying fauna: Gastropoda, Bivalvia.

S 82/508, coenote close to the type-locality; water table at $7 \mathrm{~m}$; water depth $0.5 \mathrm{~m}$; incomplete darkness; chlorinity 1440 mg/l; 1-III-1982; about 80 specimens. Accompanying fauna: Harpacticoida, Insecta, Gastropoda.

S $82 / 510$, other coenote close to the type-locality; water table at $5 \mathrm{~m}$; water depth $0.5 \mathrm{~m}$; incomplete darkness; chlorinity $23,200 \mathrm{mg} / \mathrm{l}$; 1 specimen; no other fauna.

$\mathrm{S} 82 / 512$, a horizontal cave, about $150 \mathrm{~m} \mathrm{S.W.W}$. of the type-locality; the water forms pools between large klastic boulders, in the inferior level of the practically dark cave; water clear; chlorinity $1020 \mathrm{mg} / \mathrm{l} ; 5$ specimens. Accompanying fauna: Cyclopidae, Anthuridae, hadziid Amphipoda.

Localities outside the Peninsula de Morocoy: S 82/519, manantial de "Quevey" in the village La Peña (near San Luis), Sierra de San Luis, Edo. Falcon $\left(11^{\circ} 07^{\prime} 22^{\prime \prime} \mathrm{N}\right.$ $69^{\circ} 45^{\prime} 07^{\prime \prime} \mathrm{W}$ ); limnocrene spring in dry bed of rivulet with large boulders; bottom very muddy with much vegetal material; chlorinity $200 \mathrm{mg} / \mathrm{l}$; 3-III-1982; 2 specimens. Accompanying fauna: Tricladida, Nematoda, Oligochaeta, Insecta; Ostracoda: Pseudocandona antilliana.

S 82/522, hole dug in the sandy banks of Rio Mitare (near Cabure), Sierra de San Luis, Edo. Falcon $\left(11^{\circ} 08^{\prime} 24^{\prime \prime} \mathrm{N} \quad 69^{\circ} 38^{\prime} 38^{\prime \prime} \mathrm{W}\right)$; chlorinity $60 \mathrm{mg} / \mathrm{l}$; 3-III-1982; 3 specimens. Accompanying fauna: Nematoda, Oligochaeta, Insecta; Ostracoda: Candonopsis hummelincki Pseudocandona geratsi Broodbakker, 1983.

S 82/526, hole dug in coarse sand and gravel, along the banks of Rio Ricoa, at the confluence with Rio San Pablo, near the village Dos Bocas, Sierra de San Luis, Edo. Falcon $\left(11^{\circ} 18^{\prime} 33^{\prime \prime} \mathrm{N} \quad 69^{\circ} 24^{\prime} 29^{\prime \prime} \mathrm{W}\right)$; low chlorinity; 4-III-1982; 1 specimen. Accompanying fauna: Oligochaeta, Diptera.

S 82/573, hole dug in coarse sand and gravel, along the banks of Rio Zuata, $2 \mathrm{~km} \mathrm{~N}$. of San Casimiro, Edo. Aragua $\left(10^{\circ} 00^{\prime} 12^{\prime \prime} \mathrm{N} 66^{\circ} 59^{\prime} 50^{\prime \prime} \mathrm{W}\right)$; chlorinity $19 \mathrm{mg} / \mathrm{l}$; 10-III-1982; 4 specimens. Accompanying fauna: Harpacticoida, Calabozoa pellucida Van Lieshout, 1983 (Isopoda); Ostracoda: Pseudocandona geratsi, Candonopsis hummelincki.

\section{Description}

Relative lengths of some setae and segments of most appendages are given in table $I$.

Carapace (figs. 12A-B):

The carapace is very elongate, smooth, sparsely hairy, and whitish transparent, probably because of conservation in formalin. Hinge adont. Muscle scars as typical of the Cypridinae. In dorsal view greatest width in the middle, being $32 \%$ of the length. In lateral view greatest height in front of the middle at 27 to
$34 \%$ of the length, the greatest height being 38 to $41 \%$ of the length. Left valve larger than right valve, especially in length, overlap greater posteriorly than anteriorly. Carapace very elongate. Dorsal margin practically straight in the middle, but passing smoothly in the broadly rounded anterior margin and the acuminated posterior margin. The decline of the dorsal margin is posteriorly larger because the carapace is acuminated posteroventrally. Ventral margin only slightly sinuate, left as well as right valve with a lip-like projection anteroventrally, which is stronger developed in the right valve, with simple straight marginal pore canals. Some more, but shorter, marginal pore canals can be seen more anteriorly. In the left valve shorter marginal pore canals are present anteroventrally and anteriorly. Duplicature very wide anteriorly, small posteriorly; anteriorly striate. Selvage strongly pronounced in the left valve, with a large fringe. In the right valve not pronounced. Flange only slightly pronounced at the anteroventral part of the left valve. The carapace is more hairy anteroventrally. Male and female carapaces have the same shape, but males are smaller.

In the type-locality valves were measured from 5 males and 5 females. Males: right valves: $1.66 \times 0.64 \mathrm{~mm}$; left valves: $1.75 \times$ $0.65 \mathrm{~mm}$; females: right valves: $1.73 \times 0.65$ $\mathrm{mm}$; left valves: $1.82 \times 0.67 \mathrm{~mm}$. Two samples were taken at the type-locality, one with a Cvetkov net, and the other by rinsing out the roots of a Ficus tree. The mean length of the carapaces in both samples is practically the same. Mean length for both samples together, is for males: $1.67 \pm 0.055 \mathrm{~mm}(n=81)$, with lengths ranging from 1.56 to $1.78 \mathrm{~mm}$; and for females: $1.75 \pm 0.07 \mathrm{~mm}(n=74)$, with lengths ranging from 1.60 to $1.90 \mathrm{~mm}$. In the nearby coenote $S$ 82/508, mean lengths are practically the same: $1.66 \pm 0.044 \mathrm{~mm}$ $(n=45)$, for males; and $1.72 \pm 0.065 \mathrm{~mm}$ $(n=26)$, for females. In S 82/500, a source changed in a well, some $\mathrm{km}$ away, the animals were smaller: mean length for males is: $1.59 \pm$ $0.04 \mathrm{~mm}(n=22)$; and for females: $1.66 \pm$ $0.04 \mathrm{~mm}(n=31)$. The mean length difference 


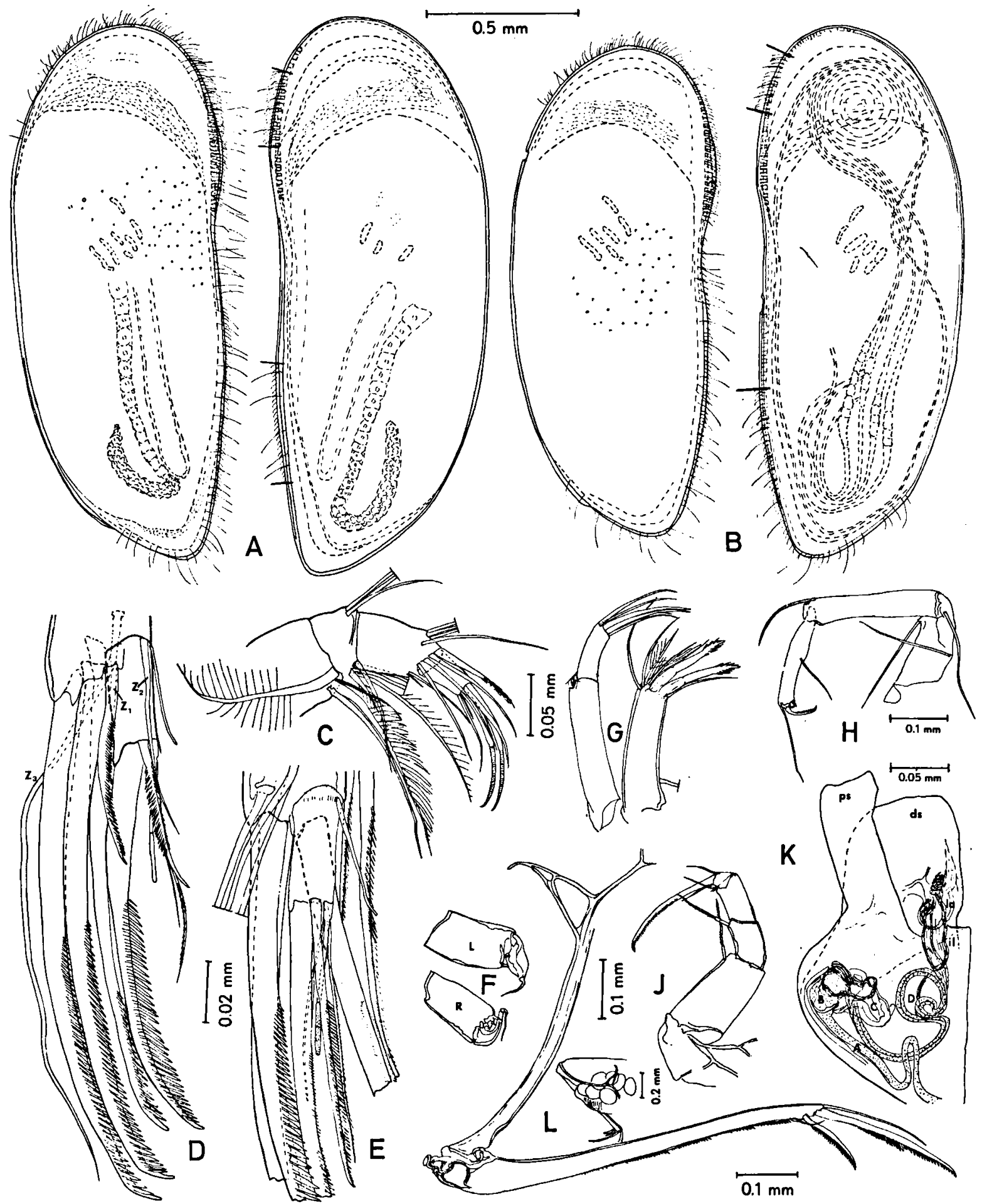

Fig. 12. Strandesia venezolana n. sp. (coenote in Mayorquines, Venezuela, S 82/509; A, C, E, G-J, L, \& holotype; B, D, $\sigma^{\circ}$ allotype; F, K, $\sigma^{\circ}$ paratype): A, B, right and left valves in lateral view; C, mandibular palp; D, E, details of second antennae; F, male maxillar endopodites; G, maxillula; H, second thoracopod; J, first thoracopod; K, hemipenis (A, B, C, D = sleeves of the labyrinth, ds = distal shield, il = inner lobe, la = latch, ps = proximal shield); L, furca with furcal attachment, and posterior part of body. 
is probably caused by differences in environmental circumstances. The other samples with $S$. venezolana contained only a few specimens.

Antennule (A 1):

Chaetotaxy the same as in $S$. longula. Only the short seta of the fifth segment is shorter, just reaching the top of the seventh segment. The third segment and aesthetasc $y_{a}$ are slightly longer than in $S$. longula. All long setae are plumose.

Second antenna (A 2) (figs. 12D-E):

In the female one of the t-setae is very strong, claw $G_{2}$ is shorter and with stronger teeth than the other claws. The distal setae of segment $\mathrm{E}$ IV are longer than in the male. In both males and females, the claws are hooked at the tops. The chaetotaxy of the male antenna is as in males of $S$. botosaneanui, with a short doubly serrate claw $G_{m}$, which is on one side only slightly serrate; a very strongly serrate $G_{M}$; two transformed and transposed $z$-setae, of which one is changed in a short seta and the other in a slightly curved, serrate claw. The t-setae are less strong than in the female, but all plumose.

Mandibular palp (Mdp) (fig. $12 \mathrm{C}$ ):

Chaetotaxy and structure as in the other Strandesia species. But the nameless seta of the first segment is long instead of reduced as in $S$. longula. Seta $\alpha$ is long and smooth, $\gamma$ is long and pappose.

The chaetotaxy and structure of the maxillula (fig. 12G), maxilla (fig. 12F), and the first and second thoracopod (figs. 12 J, H), is the same as in the species of the longula group.

Furca (Fu) (fig. 12L):

The furca is of the same type as in the longula group, with strongly serrate claws, and the ramus with, in this case, five groups of spines at the posterior side. The posterior seta is weakly plumose. The anterior claw has two groups of spines.
Furcal attachment (Fuat) (fig. 12L):

The attachment possesses a triangular eyelet, with a very small eyelet distal of the first. The ventral branch is nearly as long as the dorsal branch.

\section{Copulatory organs (figs. $12 \mathrm{~K}-\mathrm{L}$ ):}

The female copulatory organs are as in $S$. longula. The Zenker's organ of the male contains about 28 whorls of spines, which is slightly more than in $S$. botosaneanui and about twice as many as in $S$. pistrix.

The hemipenis: The proximal shield is rounded rectangular. The distal shield is like a truncate boot. Sleeves A, B and C of the labyrinth are as in both other species. The coils in $\mathrm{D}$ are short, as in $S$. pistrix. The inner lobe looks like that in $S$. pistrix with some parts surrounding the copulatory tube, and a curved elongate part distally. At one end this curved part seems to pass into some other fibrous structures, while at the other end it terminates in a rake-like part connected with the outer sheath of the hemipenis by a striate structure.

Etymology. - The species is named after Venezuela, because it seems to be restricted to this country.

Taxonomic remarks. - The species has most affinities with the longula group. However, the nameless seta of the first segment of the mandibular palp is long instead of reduced, the $\gamma$ seta is long, segment II of the maxillular palp is more elongate than in the other Strandesia species described, the terminal claw of the first thoracopod is very short, and the eyelet of the furcal attachment is followed by another eyelet, as in the genus Tanycypris. The carapace shape is also very much as in Tanycypris, Stenocypris or Herpetocypris. The carapace resembles that of Herpetocypris meridana Furtos, 1936, and of Strandesia pedroensis Tressler, 1949, both species which almost certainly belong to the genus Tanycypris. These species are, however, both much smaller (1.33-1.37 $\mathrm{mm}$ ) and have the posterior seta of the furca situated almost next to the posterior claw; they will be discussed in 
part II of this paper. $S$. venezolana seems to have an intermediate place between Strandesia and Tanycypris, which is one of the indications that the genera Strandesia and Tanycypris are very closely related, and that they belong to the same tribe.

Ecology. - The species was mostly encountered in the coenotes of the Peninsula de Morocoy, of which the water tables are mostly in incomplete darkness, but five specimens were found in an almost dark, horizontal cave; and one specimen was found in a karst spring in the neighbourhood. Many specimens were found in a source which was transformed into a well. In the Sierra de San Luis, about $150 \mathrm{~km}$ west of the peninsula, the species was encountered in low numbers in river sediments, and in a limnocrene spring. It seems that the species is able to live in lentic habitats as well as in the bottom sediments of running waters. It was found at chlorinities from 19 up to 1440 $\mathrm{mg} / \mathrm{l}$, but once one specimen was encountered at a chlorinity of $23,200 \mathrm{mg} / \mathrm{l}$, which does not seem normal for this species. The species is probably epigean, but capable to a certain degree of colonizing groundwater habitats. In spite of its large size, the species seems to live also in the interstitial of running waters, together with Candoninae.

\section{REDESCRIPTION OF FOUR STRANDESIA SPECIES FROM BRAZIL}

Sars (1901) described six species, belonging to a new genus, Neocypris, which he reared from dried mud coming from Itatiba and São Paulo, in Brazil. One of these species, $N$. gladiator, was already described as Acanthocypris bicuspis by Claus (1892). Another one, N. mucronata, possesses a posterior spine on the right valve, just as in $S$. trispinosa and the other species mentioned in the discussion about $S$. trispinosa $(S$. centrura Klie, 1940). The four remaining species are all subelliptical in shape, resembling the newly described species from the Caribbean. Because of the very brief descriptions Sars made of these species, it was decided to redescribe them and to compare them with the Caribbean species.

Of each of the four species, four to six specimens were sent to me by Dr. M. E. Christiansen, from the Zoological Museum in Oslo (ZMO). For each of the species a lectotype was designated and dissected. All this material is deposited in the Oslo Museum. The carapaces of the species were described well enough by Sars (1901). Therefore only a few additional remarks concerning the carapaces are necessary. Relative lengths of some segments and setae of the appendages are given in table I.

\section{Strandesia variegata (Sars, 1901)}

(Figs. 13F, J, N, 14D)

Neocypris variegata Sars, 1901: 33-34; pl. VII figs. 14-16.

Material. - Many specimens reared from dried mud from São Paulo, Brazil (ZMO F 19405).

Carapace (fig. 13J):

As described by Sars. In lateral view it has the same shape as in $S$. cavernicola, but it is considerably more tumid. The four adult specimens measure 1.37 to $1.44 \mathrm{~mm}$ in length. Sars mentions a length of $1.45 \mathrm{~mm}$.

Appendages (figs. 13F, N, 14D):

As in species from the longula group, but the third segment of A 1 is very elongate. Aesthetasc $Y$ is implanted flatly against segment E I. Mxup II is shorter than in the other species of the longula group, which makes the chelate setae seem relatively longer. $\mathrm{T} 1$ is more as in species of the stocki group. The furca is characteristic of the longula group. The furcal ramus as well as claws are armed with relatively strong, grouped spines. Seta $s_{p}$ is implanted close to the posterior claw and short and pappose. The posterior part of the body is blunted and of a rectangular shape, unlike that in the other species described. The furcal attachment has a medium long triangular eyelet.

Taxonomic remarks. - Except for the structure of T 1 and Mxup II, the species clearly belongs to the longula group of species. 
Strandesia obtusata (Sars, 1901)

(Figs. 13A, E, L, 14C)

Neocypris obtusata Sars, 1901: 34-35; pl. VIII fig. 2

Nec $S$. obtusata Furtos, 1936: 111-112, figs. 114-117.

Nec S. obtusata Tressler, 1937: 197.

Material. - Many specimens reared from dried mud from Itatiba, Brazil (ZMO F 19401).

Carapace (fig. 13A):

As described by Sars. The posterior obtuse projection of the right valve is clearly visible and not found in any other species described in this paper. The shape of the carapace is nearly as in $S$. stocki, but the lip-like projection in the right valve is only slightly pronounced. The radial cross-beams, characteristic of most Strandesia species, are clearly visible in the left valve. The six available specimens measure $1.14 \pm 0.02$ $\mathrm{mm}$ (1.11 to $1.16 \mathrm{~mm}$ ) in length. Sars mentions a length of $1.20 \mathrm{~mm}$, which is larger than in $S$. stocki, and smaller than in $S$. sphaeroidea.

Appendages (figs. 13E, L, 14C):

Structure and chaetotaxy as in the stocki group. E (II + III) in A 2 is very short compared with the claws and E I. The furca is finely bristled or denticulated. The $\beta$ seta in Mdp is short and broad. The medial shaft of the furcal attachment is comparatively slender.

Taxonomic remarks. - Except for the relatively slender furcal attachment, the species clearly belongs to the stocki group of species. The species described as $S$. obtusata by Furtos (1936) does not possess a posterior projection of the right valve like that in the specimens from Sars. Furthermore, she mentions the surface having a network of heavily walled polygonal reticulations. Klie (1940) already mentioned that this species is probably not $S$. obtusata. Therefore it must be another species, probably also belonging to the stocki group. The species is too large to be $S$. stocki $(1.33 \mathrm{~mm})$, but it could be the same as $S$. sphaeroidea, if Furtos mistook the round shallow holes in the carapace for polygonal reticulations, and if the species is more asymmetrical than illustrated.

Victor \& Fernando (1981a) could not locate the specimen described by Tressler (1937) as $S$. obtusata from Java. Since all South American species have a limited distribution and are sometimes very similar, Tressler probably mistook his specimen for $S$. obtusata. Moreover, he could never have known the exact habitus of this species because of the very brief description published by Sars (1901).

Strandesia elliptica (Sars, 1901)

(Figs. 13B, G, K, 14A)

Neocypris elliptica Sars, 1901: 35-36; pl. VIII figs. 3-4.

Material. - Some specimens reared from dried mud from Itatiba, Brazil (ZMO F 19402).

Carapace (fig. 13B):

As described by Sars, but with a very slight protrusion at the posterodorsal side of the right valve. It is more elongate than in $S$. obtusata and the other species of the stocki group. The five adult specimens measure 0.87 to $0.89 \mathrm{~mm}$ in length. Sars mentions a length of $0.90 \mathrm{~mm}$.

Appendages (figs. 13G, K, 14A):

Structure and chaetotaxy as in the other species of the stocki group. The chelate setae of Mastic 3 in Mxup are relatively shorter, as is the claw of $\mathrm{T} 1$, and the setae of T 1 : E II. The furca is very short, wide and straight. The eyelet of the furcal attachment is relatively long, and triangular.

Taxonomic remarks. - The species is very small, somewhat elongated, but the appendages are as in the stocki group. Because of decalcification, the inner structures of the valves are barely visible, as is the case with most other species. The appendages are somewhat different from those in the other species of the stocki group. Especially the short stout furca, which is, however, finely serrate as in the other species. Seta $s_{a}$ is very long and has practically the same length as the anterior claw.

Harrison \& Rankin (1976) found specimens of Strandesia in several samples taken during hydrobiological studies of the Antillean island St. Vincent. They ascribed these specimens to $S$. elliptica. In view of the present study it is 

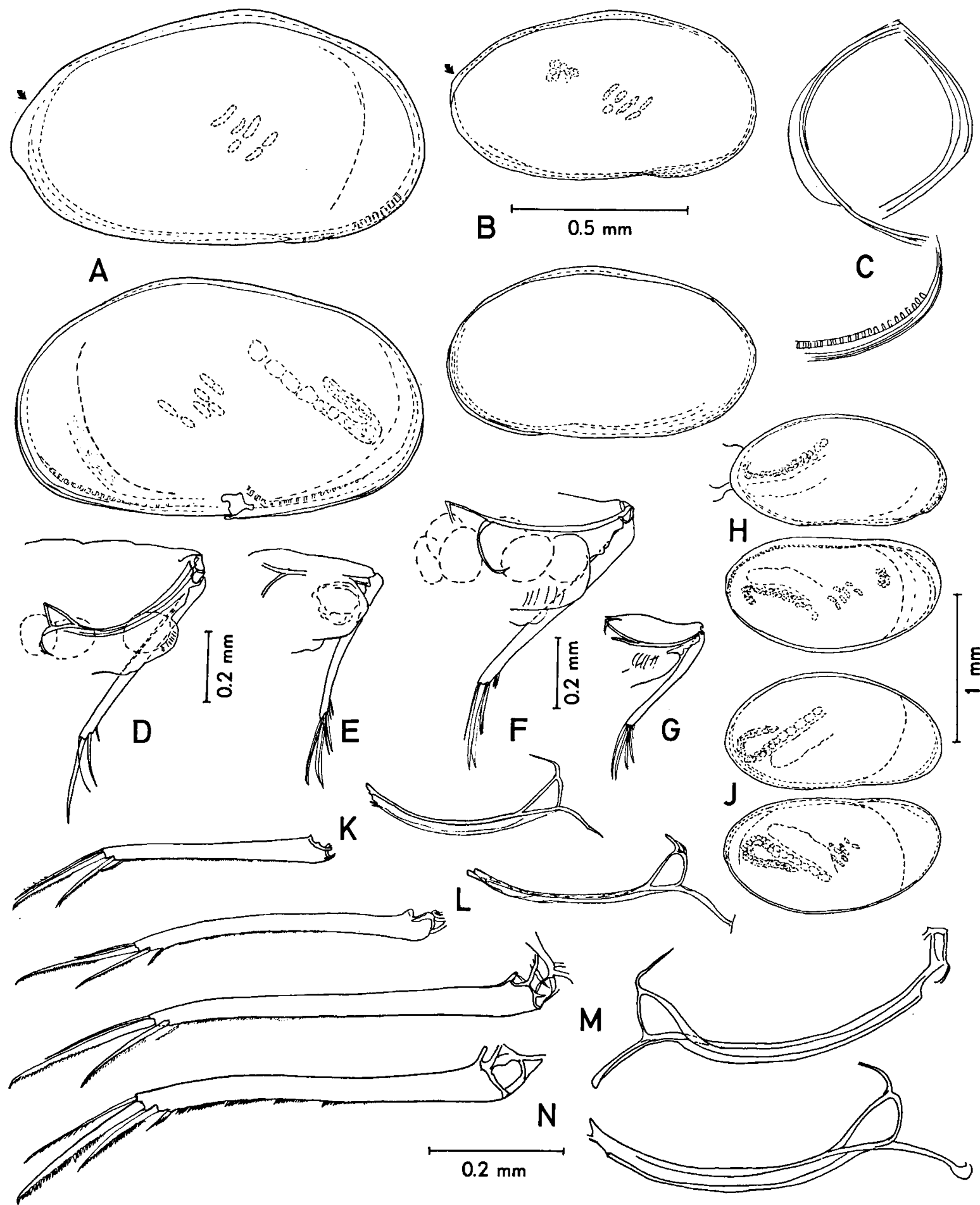

Fig. 13. A, E, L, Strandesia obtusata; B, G, K, S. elliptica; C-D, H, M, S. mutica (all three species described by Sars, 1901, from Itatiba, Brazil; ᄋ lectotypes); F, J, N, S. variegata (Sars, 1901) (São Paulo, Brazil; ᄋ lectotype): A-B, H-J, right and left valves in lateral view; $\mathrm{C}$, details of anterior and posterior parts of the right valve, and of the posteroventral part of the left valve, from inside; D-G, posterior parts of bodies; $K-N$, furcas with furcal attachments. 
almost certain that these specimens belong to $S$. stocki, because $S$. elliptica has never been found on any Caribbean island, while $S$. stocki probably is a widespread species. The material could not be traced in time, in order to ascertain this assumption.

Strandesia mutica (Sars, 1901)

(Figs. 13C-D, H, M, 14B)

Neocypris mutica Sars, 1901: 32-33; pl. VII figs. 8-13.

Material. - Many specimens reared from dried mud from Itatiba as well as São Paulo, Brazil (ZMO F 19400).

Carapace (figs. 13C, H):

As described by Sars. Characteristic is the liplike projection of the anterior outer part of the right valve, and the posterior rounded obtrusion of the same valve. The radial cross-beams are clearly visible in the left valve. The five available specimens measure 1.23 to $1.46 \mathrm{~mm}$, the two largest of which 1.44 and $1.46 \mathrm{~mm}$. Sars mentions a length of $1.60 \mathrm{~mm}$.

Appendages (figs. 13D, M, 14B):

Structure and chaetotaxy generally as in the stocki group, but some characteristics, like the structure of the first thoracopod and the furca, are more as in the longula group. The furca has grouped spines which are stronger than in the stocki group, but weaker than in the longula group. Based on the structure of the carapace, second antenna, maxillular palp and the furcal attachment, it is assigned to the stocki group.

Taxonomic remarks. - There are only few other species of Strandesia with a lip-like anterior projection of the right valve. These are $S$. feuerborni Klie, 1932, and $S$. hancocki (Lowndes, 1931). However, both have dorsal alae and the lip-like projections are much larger.

\section{Conclusions}

Three of the four species redescribed here have close affinities with $S$. stocki. Since Sars (1901) erected the genus Neocypris, in which he included the species redescribed in this paper, it is proposed to use the name for a subgenus con- sisting of all the species of the stocki group; this subgenus will be defined in the final part of the present paper.

EUROPEAN SPECIES FORMERLY ASCRIBED TO CYPRICERCUS S.L.

Strandesia (Neocypris) obliqua (Brady, 1868) (Figs. 14E, G, K)

Cypris obliqua Brady, 1868: 364; pl. XXIII figs. 33-38.

Cypricercus obliquus (Brady); Sars, 1928: 121-122; pl. LV fig. 3.

Bradleycypris obliquus (Brady); McKenzie, 1982: 415.

Material. - Many specimens; Voorste Choorven, Oisterwijkse Vennen, Prov. Noord-Brabant, The Netherlands; 13-VI-1952; coll. A. P. C. de Vos (ZMA Ost. 105.583).

Geographical distribution known. Europe, North America, North Africa.

This species, originally described from Great Britain, was encountered by many authors in other countries. The species is often confused with another species, which makes it necessary to check most of the material in museums, as was done with the present material, which was labeled Cypricercus affinis. After dissection it became clear that this species strikingly resembles the species of the stocki group (subgenus Neocypris), as can be seen in table I. Furthermore, the furcal attachment and furca are of the same type as found in this group of Strandesia s.l.

It is therefore proposed to assign this species to Strandesia subgenus Neocypris, instead of Cypricercus s.1., or Bradleycypris. S. obliqua being the type-species of Bradleycypris McKenzie, 1982, Bradleycypris becomes a subjective synonym of Neocypris. Therefore a new genus has to be erected to comprise the species with the characters described by McKenzie (1982) for Bradleycypris. It will be named:

\section{Bradleystrandesia $n$. gen.}

\section{Type-species: Bradleystrandesia fuscata} (Jurine, 1820).

(Figs. 14F, H-J) 


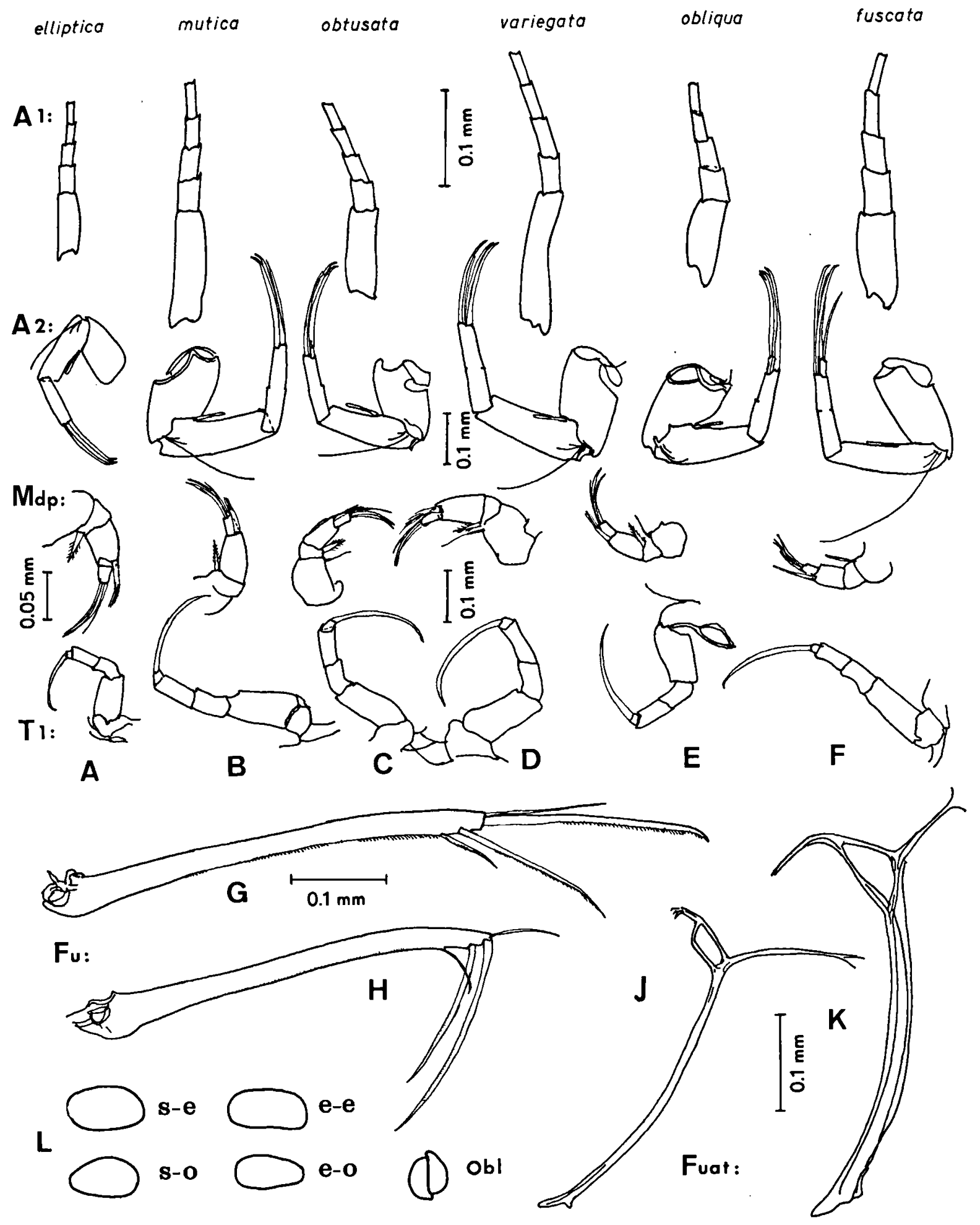

Fig. 14. A, Strandesia elliptica; B, S. mutica; C, S. obtusata (all described by Sars, 1901, from Itatiba, Brazil; $\odot$ lectotypes); D, S. variegata (Sars, 1901) (São Paulo, Brazil; ᄋ lectotype); E, G, K, Strandesia (Cypricercus) obliqua (Brady, 1868) (pool near Winterswijk, The Netherlands; \$); F, H-J, Bradleystrandesia fuscata (Jurine, 1820) (pool near Horn, The Netherlands; \& ); A 1: antennules; A 2: second antennae; Mdp: mandibular palps; T 1: first thoracopods; G, H, (Fu) furcas; J, K, (Fuat) furcal attachments; L, abbreviations used for carapace shapes in the appendix. 
Cypris fuscata Jurine, 1820: 174; pl. XIX figs. 1-2.

Cypricercus fuscatus (Jurine); Sars, 1928: 118; pl. LIV.

Bradleycypris fuscatus (Jurine); McKenzie, 1982: 415.

Material. - Many specimens; pool near Horn, Prov. Limburg, The Netherlands; 14-IV-1916; coll. H. C. Redeke (ZMA Ost. 105.508).

Geographical distribution. - Europe, North America, Iran.

This species has the type of furcal attachment described by McKenzie (1982) as characteristic of his genus Bradleycypris. The furcal claws of $B$. fuscata are very long and slender compared to the ramus. The lengths of segments and setae are partly as in the subgenus Neocypris of Strandesia, and partly as in Acanthocypris. The genus is probably closely related to the genus Strandesia, and certainly belongs to the tribe Cypricercini.

\section{DEFINITION OF THE SUBGENERA ACANTHOCYPRIS AND NEOCYPRIS}

Subgenus Acanthocypris Claus, 1892

Type-species: Acanthocypris bicuspis Claus, 1892

Klie (1930) suggested the generic name Acanthocypris to be used for species of Strandesia s.l. with a dorsal fin-like or comb-like projection (ala), on the right valve. Klie (1938) placed six species in this Acanthocypris group. Examination of the species described in the present paper reveals that the possession of a dorsal ala does not automatically mean that the species belongs to the same lineage as other species with dorsal alae. $S$. squalida and $S$. trispinosa do not have much structural properties in common with $A$. bicuspis, nor with other species with dorsal alae. The presence of dorsal alae often only indicates a homoeomorphic development, which becomes obvious in most cases when soft part morphology is studied. The most striking and often cited example of homoeomorphy is the similarity in carapace shape between Rudjakoviella prolongata (Triebel, 1962) from the Venezuelan island Margarita, and S. bicornuta Hartmann, 1964, from southern India. Both species have long anterior and posterior spines on the right valve, but are totally different in their soft part morphology. To establish relationships, soft part morphology has to be studied in the first place.

Acanthocypris bicuspis has the same type of appendages and valves as species of the longula group (except for the ala). Therefore it is suggested to use the name Acanthocypris for a subgenus consisting of all the species of a "longula-type", with the following characters:

(1) An elongated or semi-elongated carapace, height being less than $57 \%$ of the length, and only slight ventral overlap of the valves, but never with a ventral protrusion of the left valve.

(2) The furcal rami and claws armed with several groups of relatively strong spines. A characteristic already mentioned by Klie (1938) and Hartmann (1964) for dividing Strandesia s.l. in different groups. The posterior seta is short and implanted close to $G_{p}$.

Characteristics derived from table I:

Antennule (A 1): Sixth segment longer than the seventh.

Second antenna (A 2): $G_{1}$ has about the length of segment $\mathrm{E}(\mathrm{II}+\mathrm{III})$, or is shorter, and both are shorter than segment $\mathrm{E}$ I. Aesthetasc $\mathrm{Y}$ is shorter than $30 \%$ of segment $\mathrm{E}$ I. The long swimming bristles are 1.8 times the length of $\mathrm{E}$ I, but mostly shorter.

Maxillula (Mxu): The serrate, chelate setae of the third masticatory process are 1.8 times the length of Mxup II, or shorter (exception: in $S$. variegata they are 1.9 times the length of Mxup II).

Thoracopod 1 (T 1): Segment E I is twice the length of segment $\mathrm{E}$ II, or shorter. The distal claw is usually shorter than 3.1 times the length, and the seta of E II is shorter than 1.8 times the length of $\mathrm{E}$ II.

Furcal attachment (Fuat): The dorsal loop, or eyelet, is usually longer than $20 \%$ of the median shaft.

Practically all species attributed to Acanthocypris have been found in South America and the 
Caribbean. There are some species with a strongly serrate furca in Asia and Africa, but these seem to disagree with the Neotropical species in other aspects as carapace shape and antennal structure.

All species of Acanthocypris are large, Strandesia cavernicola being the smallest species, measuring $1.14 \mathrm{~mm}$ in length. All others are $1.4 \mathrm{~mm}$ or larger. The species which are assumed to belong to this subgenus are indicated in the appendix.

Subgenus Neocypris Sars, 1901

Type-species: Neocypris obtusata Sars, 1901

As mentioned before, species which are more or less subelliptical, rather tumid, with a finely serrate furca, are assigned to this subgenus. Eventually, this group may be divided into two other groups, one consisting of the species with a more pronounced asymmetry between the right and left valve, the left valve protruding ventrally over the right valve, and the right valve dorsally somewhat over the left valve, giving the carapace an oblique aspect, when viewed from the anterior or posterior side. $S$. sphaeroidea is a fine example of this group. The second group is more symmetrical, like $S$. stocki and the species described by Sars (1901). Characteristics of the subgenus:

(1) Carapace subelliptical, broadly rounded, width more than $50 \%$ of the length.

(2) Furcal rami and claws finely serrate. Sometimes with grouped spines.

Characteristics derived from table I:

Antennule (A 1): Sixth segment as long as or shorter than the seventh.

Second antenna (A 2): The claw $G_{1}$ and segment $\mathrm{E} I$ are both much longer than segment $\mathrm{E}(\mathrm{II}+\mathrm{III})$. The distal claws are long and slender, and hooked at their tips. Aesthetasc Y is usually longer than $30 \%$ of the length of $\mathrm{E} \mathrm{I}$. The long swimming bristles are 1.9 times the length of $\mathrm{E} I$ or longer.

Maxillula (Mxu): The second segment of the palp is twice as long as wide or shorter. The serrate, chelate setae of the third masticatory pro- cess are usually more than twice the length of Mxup II (exception: in $S$. elliptica they are 1.8 times the length).

Thoracopod 1 (T 1): Segment E I is more than twice the length of segment E II. The distal claw is usually more than three times as long as E II (in S. elliptica it is 2.9 times the length). The seta of E II is usually more than twice the length of E II.

Furcal attachment (Fuat): Usually short and stout (except in $S$. obtusata), with a short triangular eyelet.

Most species of Neocypris seem to be found in South America, Africa and Europe. However, some are also found in Asia. More or less oblique carapaces are found in many species of Strandesia (Neocypris) in Africa. A number of these species have been described by Rome in several papers. The most strongly asymmetric species are $S$. asymmetros, from lake Tanganyika, $S$. vittata, from China, Ceylon and Celebes (Sulawesi), and $S$. nec obliqua Klie, from Brazil. Sars (1903) mentioned the similarity in carapace shape between $S$. vittata and $C$. obliquus Brady, a species which also has to be placed in this subgenus. $S$. clorocelis and $S$. mulargia, both described by Anichini (1967) from Sardinia (Italy) also have the characteristics of Neocypris. It seems that the slightly oblique type of Neocypris is the most widely distributed Strandesia, and maybe even cosmopolitan.

\section{ACKNOWLEDGEMENTS}

Dr. D. L. Danielopol is thanked for his support and the many contributions to my research project. Prof. Dr. J. H. Stock, Dr. L. Botosaneanu, Drs. F. Pieters, and Dr. D. L. Danielopol are thanked for critically reviewing the manuscript.

Dr. P. Wagenaar Hummelinck, Dr. L. Botosaneanu, and Dr. T. Orghidan kindly put their sampled material at our disposal. The material from Sars (1901) was kindly made available by Dr. M. E. Christiansen of the Zoologisk Museum in Oslo (Norway). Prof. Dr. J. H. Stock coordinates this project.

Maarten Schoonoord, a promising young biologist and pleasant human being, made the SEM photographs. He unfortunately died of a disease recently. 


\section{TABLE I}

Relative lengths of some segments and setae of the appendages of 8 species of Strandesia from the West Indies, 4 from Brazil, 1 from Europe, and one species of Bradleystrandesia from Europe. Abbreviations used: eye = eyelet; le = length; $\mathrm{ms}=$ medial shaft; $\mathrm{S}=$ seta; $\mathrm{swim}=$ swimming bristle; $\mathrm{vb}=$ ventral branch; $\mathrm{w}=$ width. For further abbreviations, see Broodbakker \& Danielopol, 1982: 114.

\begin{tabular}{|c|c|c|c|c|c|c|c|c|c|c|c|c|c|c|c|}
\hline & $\begin{array}{l}\text { A 1: } \\
\mathrm{y}_{\mathrm{a}} / \text { III }\end{array}$ & III & IV & V & VI: & VII & $\begin{array}{l}\text { A 2: } \\
\text { E I : }\end{array}$ & $(\mathrm{II}+\mathrm{III})$ & $\mathrm{G}_{1}$ & Y/E I & $\mathrm{y}_{2} / \mathrm{E} \mathrm{I}$ & $\mathrm{y}_{3} / \mathrm{E} \mathrm{I}^{l}$ & $\frac{l \text { swim }}{\text { E I }}$ & $\frac{l \text { swim }}{\mathrm{E}(\mathrm{II}+\mathrm{III})+\mathrm{G}_{1}}$ & $\frac{s \text { swim }}{\text { E I }}$ \\
\hline S. longula & 1.2 & 2.8 & 1.1 & 1.1 & 1.2 & 1 & 1.5 & 1.05 & 1 & $22 \%$ & $18 \%$ & $22 \%$ & 1.7 & 1.2 & $42 \%$ \\
\hline S. cavernicola & 1.9 & 2.9 & 1.5 & 1.5 & 1.4 & 1 & 1.7 & 1.1 & 1 & $28 \%$ & $9 \%$ & $30 \%$ & 1.2 & 1.0 & $33 \%$ \\
\hline S. botosaneanui & 2.0 & 2.7 & 1.2 & 1.3 & 1.3 & 1 & 1.4 & 1.0 & 1 & $21 \%$ & $16 \%$ & $32 \%$ & 1.6 & 1.1 & $44 \%$ \\
\hline S. stocki & 1.2 & 2.6 & 1.1 & 1 & 1.0 & 1.1 & 1.2 & 1 & 1.2 & $37 \%$ & $24 \%$ & $35 \%$ & 2.1 & 1.2 & $43 \%$ \\
\hline S. sphaeroidea & 0.6 & 3.0 & 1.3 & 1.1 & 1 & 1.0 & 1.2 & 1.0 & 1.2 & $34 \%$ & $12 \%$ & $24 \%$ & 2.1 & 1.2 & $45 \%$ \\
\hline$S$. pistrix & 1.2 & 3.3 & 1.2 & 1.2 & 1 & 1.1 & 1.3 & 1 & 1.3 & $44 \%$ & $22 \%$ & $35 \%$ & 2.1 & 1.2 & $38 \%$ \\
\hline S. tripinosa galantis & 0.8 & 2.7 & 1.3 & 1.1 & 1 & 1.1 & 1.3 & 1 & 1.3 & $35 \%$ & $22 \%$ & $35 \%$ & 2.1 & 1.2 & $55 \%$ \\
\hline S. venezolana & 1.3 & 3.4 & 1.3 & 1.2 & 1.3 & 1 & 1.4 & 1.1 & 1 & $24 \%$ & $\begin{array}{c}17 \% \\
\text { E I } \\
\text { le/w }\end{array}$ & $\begin{array}{l}22 \% \\
\text { E II } \\
\text { le/w }\end{array}$ & 1.8 & 1.2 & $48 \%$ \\
\hline S. variegata & - & 4.5 & 1.2 & 1.4 & 1.2 & 1 & 1.3 & 1.1 & 1 & $24 \%$ & 3.0 & 4.6 & 1.7 & - & - \\
\hline S. obtusata & 1.1 & 2.9 & 1.1 & 1 & 1 & 1.1 & 1.5 & 1 & 1.6 & $39 \%$ & 3.7 & 3.5 & 1.9 & - & - \\
\hline S. elliptica & 1.1 & 3.5 & 1.5 & 1.3 & 1 & 1.1 & 1.4 & 1 & 1.4 & $34 \%$ & 2.8 & 3.3 & 1.9 & - & - \\
\hline S. mutica & 1.0 & 4.3 & 1.4 & 1.3 & 1 & 1.4 & 1.3 & 1 & 1.2 & $30 \%$ & 2.9 & 2.3 & 1.9 & - & - \\
\hline S. obliqua & 1.8 & 2.7 & 1.2 & 1 & 1 & 1.0 & 1.4 & 1 & 1.5 & $29 \%$ & 3.0 & 3.6 & 1.9 & - & - \\
\hline B. fuscata & 1.2 & 2.2 & 1.0 & 1 & 1.1 & 1 & 1.3 & 1 & 1.3 & $25 \%$ & 3.7 & 4.8 & 2.0 & - & - \\
\hline
\end{tabular}

A 2: Mdp:

Mxup II:

T 1:

$\underline{l \text { Exo }} \quad \underline{\alpha} \quad \underline{\beta} \quad \underline{\gamma} \quad \underline{I V} \quad \underline{\text { length }}$ Mxup II: Mastic 3:

$\overline{\text { E I }} \overline{\text { III }} \overline{\text { III }} \frac{\gamma}{\text { III }} \overline{\text { III }} \overline{\text { width }}$ cs/Mxup II cs/Mxup II E I $:$ E II $\quad:$ E III $:$ E IV $: \quad$ G

\begin{tabular}{|c|c|c|c|c|c|c|c|c|c|c|c|c|c|}
\hline S. longula & 1.0 & $55 \%$ & $55 \%$ & 1.0 & $53 \%$ & 2.4 & 1.5 to 1.7 & 1.5 & 1.9 & 1 & 1.1 & 0.3 & 3.0 \\
\hline S. botosaneanui & 0.9 & $50 \%$ & $50 \%$ & 1.3 & $56 \%$ & 2.1 & 1.7 to 2.0 & 1.7 & 1.5 & 1 & 0.9 & 0.3 & 1.8 \\
\hline S. cavernicola & 1.0 & $47 \%$ & $47 \%$ & 1.0 & $47 \%$ & 2.4 & 1.7 to 1.9 & 1.75 & 1.8 & 1 & 1 & 0.3 & 2.6 \\
\hline S. stocki & 1.1 & $116 \%$ & $30 \%$ & 1.1 & $47 \%$ & 2.0 & 2.1 to 2.3 & 2.1 & 2.4 & 1 & 1.5 & 0.3 & 3.1 \\
\hline S. sphaeroidea & 0.5 & $71 \%$ & $65 \%$ & 0.9 & $47 \%$ & 2.0 & 2.1 to 2.3 & 2.3 & 2.3 & 1 & 1.3 & 0.3 & 3.5 \\
\hline S. pistrix & 0.3 & $100 \%$ & $70 \%$ & 1.6 & $57 \%$ & 2.3 & 1.8 to 1.9 & 1.9 & 2.5 & 1 & 1.4 & 0.3 & 3.3 \\
\hline S. trispinosa galantis & 0.3 & $89 \%$ & $70 \%$ & 1.5 & $60 \%$ & 2.0 & 1.9 to 2.1 & 2.0 & 2.1 & 1 & 1.2 & 0.3 & 3.7 \\
\hline S. venezolana & 1.0 & $86 \%$ & $59 \%$ & 1.2 & $57 \%$ & 2.9 & 1.6 to 1.7 & 1.7 & 2.0 & 1 & 1.0 & 0.3 & 2.5 \\
\hline S. variegata & 1.0 & $65 \%$ & $68 \%$ & 0.8 & $40 \%$ & 2.0 & 1.9 to 2.1 & 1.9 & 2.0 & 1 & 1.3 & 0.3 & 3.1 \\
\hline S. obtusata & 1.1 & $76 \%$ & $71 \%$ & 1.0 & $48 \%$ & 1.5 & 2.0 to 2.3 & 2.2 & 2.2 & 1 & 1.4 & 0.4 & 3.8 \\
\hline S. elliptica & 1.0 & $70 \%$ & $70 \%$ & 1.1 & $44 \%$ & 1.9 & 1.6 to 1.9 & 1.8 & 2.2 & 1 & 1.3 & 0.3 & 2.9 \\
\hline$S$. mutica & 1.0 & - & $66 \%$ & 0.9 & $45 \%$ & 2.0 & 1.8 to 2.1 & 2.1 & 2.1 & 1 & 1.1 & 0.3 & 3.0 \\
\hline S. obliqua & 1.0 & $68 \%$ & $78 \%$ & 1.0 & $51 \%$ & 1.9 & 1.9 to 2.1 & 2.0 & 2.1 & 1 & 1.1 & 0.3 & 3.6 \\
\hline B. fuscata & 1.3 & $93 \%$ & $78 \%$ & 1.3 & $54 \%$ & 2.4 & 1.5 to 1.7 & 1.6 & 1.9 & 1 & 0.9 & 0.3 & 3.0 \\
\hline
\end{tabular}

\begin{tabular}{|c|c|c|c|c|c|c|c|c|c|c|c|c|}
\hline & $\begin{array}{c}\text { T 1: } \\
\text { S(E I) }\end{array}$ & S(E II) & $\begin{array}{c}\text { T 2: } \\
\text { S(E I) }\end{array}$ & $\mathrm{S}(\mathrm{E}$ & Fuat: & & & Fu: & & & & \\
\hline & E II & E II & E I & E I & $\mathrm{ms} / \mathrm{w}$ & eye/ms & $\mathrm{vb} / \mathrm{ms}$ & $R / w$ & $\mathrm{G}_{\mathrm{a}} / \mathrm{R}$ & $G_{p} / G_{a}$ & $\mathbf{s}_{\mathbf{a}} / \mathrm{G}_{\mathrm{a}}$ & $s_{p} / G_{p}$ \\
\hline S. longula & 1.0 & 1.4 & $73 \%$ & $39 \%$ & 19 & $26 \%$ & $24 \%$ & 18 & $39 \%$ & $53 \%$ & $66 \%$ & $29 \%$ \\
\hline S. cavernicola & 0.9 & 1.3 & $58 \%$ & $41 \%$ & 25 & $21 \%$ & $24 \%$ & 19 & $42 \%$ & $56 \%$ & $78 \%$ & $38 \%$ \\
\hline S. botosaneanui & 1.2 & 1.5 & $74 \%$ & $37 \%$ & 17 & $23 \%$ & $33 \%$ & 15 & $44 \%$ & $71 \%$ & $58 \%$ & $37 \%$ \\
\hline S. stocki & 1.7 & 2.4 & $61 \%$ & $28 \%$ & 14 & $18 \%$ & $25 \%$ & 19 & $49 \%$ & $76 \%$ & $60 \%$ & $32 \%$ \\
\hline S. sphaeroidea & 1.7 & 2.2 & $61 \%$ & $32 \%$ & 13 & $18 \%$ & $15 \%$ & 18 & $41 \%$ & $68 \%$ & $82 \%$ & $58 \%$ \\
\hline S. pistrix & 1.4 & 2.0 & $64 \%$ & $40 \%$ & 26 & $15 \%$ & $29 \%$ & 22 & $38 \%$ & $90 \%$ & $52 \%$ & $30 \%$ \\
\hline S. trispinosa galantis & 1.2 & 1.9 & $53 \%$ & $35 \%$ & 28 & $15 \%$ & $52 \%$ & 29 & $57 \%$ & $83 \%$ & $17 \%$ & $14 \%$ \\
\hline S. venezolana & 1.3 & 1.4 & $72 \%$ & $39 \%$ & 19 & $21 \%$ & $22 \%$ & 21 & $44 \%$ & $50 \%$ & $75 \%$ & $44 \%$ \\
\hline S. variegata & 1.7 & 1.8 & $70 \%$ & $51 \%$ & 15 & $22 \%$ & $29 \%$ & 16 & $41 \%$ & $72 \%$ & $80 \%$ & $24 \%$ \\
\hline S. obtusata & 1.8 & 2.0 & $58 \%$ & $40 \%$ & 21 & $20 \%$ & $29 \%$ & 17 & $45 \%$ & $61 \%$ & $47 \%$ & $32 \%$ \\
\hline S. elliptica & 1.7 & 1.6 & $62 \%$ & $40 \%$ & 13 & $25 \%$ & $27 \%$ & 14 & $47 \%$ & $65 \%$ & $97 \%$ & $28 \%$ \\
\hline S. mutica & 1.5 & 2.1 & $57 \%$ & $39 \%$ & 15 & $19 \%$ & $25 \%$ & 17 & $43 \%$ & $76 \%$ & $68 \%$ & $25 \%$ \\
\hline S. obliqua & 1.6 & 1.9 & $68 \%$ & $42 \%$ & 15 & $22 \%$ & $21 \%$ & 21 & $49 \%$ & $73 \%$ & $52 \%$ & $26 \%$ \\
\hline B. fuscata & 1.1 & 1.5 & $58 \%$ & $36 \%$ & 28 & $14 \%$ & $38 \%$ & 18 & $53 \%$ & $73 \%$ & $33 \%$ & $32 \%$ \\
\hline
\end{tabular}


Louis van der Laan is thanked for developing and printing the photographs.

This study has been financed by the Netherlands Foundation for the Advancement of Tropical Research (WOTRO), The Hague. The fieldwork of the Amsterdam Expeditions has been supported by grants from WOTRO, the Beijerinck-Popping Fonds (Amsterdam), the Treub Maatschappij (Utrecht), the Amsterdamse Universiteits Vereniging (Amsterdam), and the Fonds Landbouwhogeschool (Wageningen).

Logistic support is acknowledged from the Fundación La Salle (Caracas), the Sociedad Venezolana de Ciencias Naturales (Caracas), the management of its Estación Biologica (Calabozo), and H. M. Embassy of the Netherlands (Caracas).

\section{REFERENCES}

Akatova, N. A., 1958. Strandesia spinulosa Bronsi in (in litt.) sp. n. (Ostracoda) (in Russian). Dokl. Akad. Nauk tadzhik. SSR, 1(4): 37-39.

Alm, G., 1915. Monographie der Schwedischen Süsswasser-Ostracoden nebst systematischen Besprechungen der Tribus Podocopa. Zool. Bidr. Upps., 4: 1-248.

Anichini, G., 1967. Gli ostracodi della Sardegna: 1. Forme reperite nel bacino del flumendosa. Rc. Semin. Fac. Sci. Univ. Cagliari, 37: 175-216.

Botosaneanu, L., 1970. L'Expédition biospéologique à Cuba (mars-juin 1969), organisée par les Académies des Sciences de Cuba et de Roumanie: Présentation sommaire des stations explorées pour le prélèvement d'échantillons de faune aquatique souterraine. Trav. Inst. Spéol. Emile Racovitza, 9: 81-95.

Brady, G. S., 1868. A monograph of the recent British Ostracoda. Trans. Linn. Soc. Lond., 26: 353-495, pls. XXIII-XLI.

-, 1886 . Notes on Entomostraca collected by Mr. A. Haly in Ceylon. J. Linn. Soc., (Zool.) 19: 293-317.

BreHM, V., 1934. Über südamerikanische Ostracoden des Zoologischen Staatsinstitutes und Museums in Hamburg. Zool. Anz., 108: 74-85.

douce d'Angola. IV. Cladoceren und Ostracoden. Arch. Hydrobiol., 32: 488-502.

Bronstein, Z. S., 1947. Faune de l'URSS. Crustacés II (1). Ostracodes des eaux douces. Fauna SSSR, (N.S.) 31: 1-334, pls. I-XIV (in Russian).

Broodbakker, N. W., 1982. The genus Heterocypris (Crustacea, Ostracoda) in the West Indies. Part I. Taxonomic characters. Bijdr. Dierk., 52 (2): 207-227.

- , 1983a. The genus Heterocypris (Crustacea, Ostracoda) in the West Indies. Part II. Carapace length, ecology and zoogeography. Bijdr. Dierk., 53 (1): 115-134.
- 1983b. The genus Hemicypris (Crustacea, Ostracoda) in the West Indies. Bijdr. Dierk., 53 (1): 135-157.

-, $1983 \mathrm{c}$. The subfamily Candoninae (Crustacea, Ostracoda) in the West Indies. Bijdr. Dierk., 53 (2): 287-326.

Broodbakker, N. W \& D. L. Danielopol, 1982. The chaetotaxy of Cypridacea (Crustacea, Ostracoda) limbs: proposals for a descriptive model. Bijdr. Dierk., 52 (2): 103-120.

Claus, C., 1892. Beiträge zur Kenntnis der SüsswasserOstracoden. Arb. Zool. Inst. Univ. Wien, 10 (2): 147-216, pls. I-XII.

DadAY, E. von, 1898. Mikroskopische Süsswassertiere aus Ceylon. Természetr. Füz., Suppl. 21: 1-123.

- - 1905. Untersuchungen über die Süsswassermikrofauna Paraguays. IV. Ostracoda. Zoologica, Stuttg., 44: 234-270.

Danielopol, D. L., 1976. The superfamily Cypridacea: some remarks on the phylogenetical affinities between the main ostracod cypridacean groups. In: G. Hartmann ed., Proceedings of the 5th International Symposium on evolution of Post-Paleozoic Ostracoda. Abh. Verh. naturw. Ver. Hamburg, (N.F.) 18/19 (Suppl.): 77-85, pls. 1-2.

-, 1978 . Über Herkunft und Morphologie der Süsswasser-hypogäischen Candoninae (Crustacea, Ostracoda). Sber. öst. Akad. Wiss., math.-naturw. Kl., (I) 187 (1-5): 1-162.

- 1 1980. On the carapace shape of some European freshwater interstitial Candoninae (Ostracoda). Proc. biol. Soc. Wash., 93 (3): 742-756.

-, 1982 . The preparation of ostracod limbs, for optical microscopy (dissection, staining and mounting procedures). In: R. F. MADDocks ed., Eighth International Symposium on Ostracoda, July 26-29, 1982. Programs and abstracts: 41-43 (Department of Geosciences, University of Houston).

Danielopol, D. L. K. G. McKenzie, 1977. Psychrodromus gen. n. (Crustacea, Ostracoda), with redescription of the cypridid genera Prionocypris and Ilyodromus. Zoologica Scr., 6 (4): 301-322.

Fox, H. M., 1964. New and interesting cyprids (Crustacea, Ostracoda) in Britain. Ann. Mag. nat. His., (13) 7: 623-633.

Furtos, N. C., 1936. On the Ostracoda from the cenotes of Yucatan and vicinity. In: A. S. Pearse, E. P. Creaser \& F. G. Hall eds., The cenotes of Yucatan; a zoological and hydrographic survey. Publs. Carnegie Instn., 457: 89-115.

Gauthier, H., 1951. Contribution à l'étude de la faune des eaux douces au Sénégal (Entomostracés): 1-169, pls. 1-38 (Imprimerie Minerva, Alger).

Grochmalicki, J., 1915. Beiträge zur Kenntnis der Süsswasserfauna Javas. Phyllopoda, Copepoda und Ostracoda. Anz. Akad. Wiss. Krakau, math.naturw. Kl. (B) 1915: 217-242. 
Harrison, A. D. \& J. J. Rankin, 1976. Hydrobiological studies of eastern Lesser Antillean Islands. II. St. Vincent: Freshwater fauna - its distribution, tropical river zonation and biogeography. Arch. Hydrobiol., Suppl. 50: 275-311.

Hartmann, G., 1964. Asiatische Ostracoden. Systematische und zoogeographische Untersuchungen. Int. Revue ges. Hydrobiol., Syst. Beih., 3: 1-155.

- - 1965. Zur Kenntnis des Sublitorals der chilenischen Küste. Unter besonderer Berücksichtigung der Polychaeten und Ostracoden. III. Ostracoden des Sublitorals. Mitt. hamb. zool. Mus. Inst., 62 (Suppl.): 307-384.

Hartmann, G. \& H. S. Puri, 1974. Summary of neontological and paleontological classification of Ostracoda. Mitt. hamb. zool. Mus. Inst., 70: 7-73.

Hedges, S. B., 1982. Caribbean biogeography: implications of recent plate tectonic studies. Syst. Zool., 31 (4): 518-522.

Hummelinck, P. WagenaAR, 1940a. General information. Stud. Fauna Curaçao, 1 (1): 1-58.

- , 1940b. Descriptions of the localities. Stud. Fauna Curaçao, 2 (4): 1-42.

- 1 1953. Description of new localities. Stud. Fauna Curaçao, 4 (17): 1-108.

- , 1981. Land and fresh-water localities. Stud. Fauna Curaçao, 63 (192): 1-133, pls. I-IL.

Jurine, L., 1820. Histoire des monocles; qui se trouvent aux environs de Genève: i-xvi, 1-260, pls. I-XXII. (J. J. Paschoud, Genève).

KLIE, W., 1930. Ostracoden aus dem paraguayischen Teile des Gran-Chaco. Arch. Hydrobiol., 22: 221-258.

- , 1932. Die Ostracoden der Deutschen Limnologischen Sunda-Expedition. Arch. Hydrobiol., Suppl. 11: 447-502.

- 1935 . Ostracoda aus dem tropischen Westafrika. Voyage de Ch. Alluaud et P. A. Chappuis en Afrique occidentale française (1930-1931). Arch. Hydrobiol., 28: 35-68.

-, 1936. Ostracoden aus Kamerun. Revue Zool. Bot. afr., 28: 287-309.

-, 1938 . Ostracoden aus dem belgischen Kongogebiet. Revue Zool. Bot. afr., 30: 364-388.

- - 1939. Ostracoden aus dem Kenia-Gebiet, vornehmlich von dessen Hochgebirgen. Int. Revue ges. Hydrobiol. Hydrogr., 39: 99-161.

- , 1940. Süsswasserostracoden aus Nordostbrasilien. V. Die Gattung Strandesia. Zool. Anz., 129: 201-206.

- - 1944. Ostracoda. Explor. Parc natn. Albert Miss. H. Damas (1935-1936), 12: 3-62.

Lowndes, A. G., 1931. A small collection of Entomostraca from Uganda, collected by Mr. G. L. R. Hancock. Proc. zool. Soc. London, 1931 (4): 1291-1299, pls. I-VI.

Maddocks, R. F., 1969. Recent ostracods of the family
Pontocyprididae chiefly from the Indian Ocean. Smithson. Contr. Zool., 7: 1-56.

Masi, L., 1905. Nota sopra una nuova specie di Cypris sessuata e sulla Cypris bispinosa. Monitore zool. ital., 16: 240-241.

McKenzie, K. G., 1966. Freshwater Ostracoda from north western Australia. Aust. J. mar. Freshwat. Res., 17: 259-279.

- , 1971a. Palaeozoogeography of freshwater Ostracoda. In: H. J. Oertli ed., Paléoécologie des Ostracodes. Bull. Cent. Rech. Pau, Suppl. 5: 207-237.

- $1971 \mathrm{~b}$. Species list of South African freshwater Ostracoda with an appendix listing museum collections and some further determinations. Ann. S. Afr. Mus., 57 (9): 157-213.

- , 1982. Homoeomorphy: Persistant joker in the taxonomic pack, with the description of Bradleycypris gen. nov. In: R. H. Bate, E. Robinson \& L. M. ShEPPARD eds., Fossil and recent ostracods: 407-438 (Ellis Horwood Limited for British Micropaleont. Soc., London).

Méhes, G., 1913. Süsswasser-Ostracoden aus Columbien und Argentinien. Mém. Soc. neuchât. Sci. nat., 5: 639-663.

-, 1939 . Ostracodes de la Nouvelle Calédonie. Revue suisse Zool., 46: 549-566.

Moniez, R., 1892. Entomostracés d'eau douce de Sumatra et de Célèbes. II. Ostracodes. In: M. Weber ed., Zoologische Ergebnisse einer Reise in Niederländisch Ost-Indien, 2: 129-135, pl. X figs. 6-27 (E. J. Brill, Leiden).

Müller, G. W., 1898. Wissenschaftliche Ergebnisse der Reisen in Madagascar und Ostafrika in den Jahren 1889-95 von Dr. A. Voeltzkow. Heft II. Die Ostracoden. Abh. senckenb. naturforsch. Ges., 21: 257-296, pls. XIII-XIX.

- - 1906. Ostracoden aus Java. Mitt. hamb. zool. Mus. Inst., 23: 139-142.

- 1912 . Ostracoda. Tierreich, 31: 1-434.

Petkovski, T. K., 1964. Bemerkenswerte Entomostraken aus Jugoslavien. Acta Mus. maced. Sci. nat., 9 (7): 147-181.

Pinto, I. D. I. Purper, 1965. A new fresh-water ostracode Cyprinotus trispinosus Pinto et Purper, sp. nov., from southern Brazil, its ontogenetic carapace variation and seasonal distribution. Esc. Geol. P. Alegre Publiçôes Esp., 7: 1-53.

Rome, D. R., 1962. Ostracodes. Résult. scient. Explor. hydrobiol. Lac Tanganyika (1946-1947), 3 (8): 1-305.

- - 1964. Ostracodes. Explor. Parc natn. Upemba Miss. G. F. de Witte, 69: 3-71.

-, 1969. Morphologie de l'attache de la furca chez les Cyprididae et son utilisation en systématique. In: J. W. Neale ed., The taxonomy, morphology and ecology of recent Ostracoda: 168-193 (Oliver Boyd Ltd., Edinburgh). 
Rome, D. R. \& P. de Deckker, 1977. Ostracodes du Lac Kivu. Mém. Inst. geól. Univ. Louvain, 29: 241-287.

Sars, G. O., 1901. Contributions to the knowledge of the fresh-water Entomostraca of South America, as shown by artificial hatching from dried material. Part II. Arch. Math. Naturv., 24: 1-52, pls. I-VIII.

- , 1903. Freshwater Entomostraca from China and Sumatra. Arch. Math. Naturv., 25: 3-44, pls. I-IV.

- - 1924. The fresh-water Entomostraca of the Cape Province (Union of South Africa). Part II. Ostracoda. Ann. S. Afr. Mus., 20: 105-193, pls. I-XX.

- 1928 . An account of the Crustacea of Norway. Vol. IX. Ostracoda: 1-277, pls. I-CXIX (Bergen Museum, Bergen, Norway).

Stock, J. H., 1979. Amsterdam Expeditions to the West Indian Islands, Report 4. Station List. Verslagen technische Gegevens Inst. taxon. Zoöl. (Zoöl. Mus.) Univ. Amsterdam, 20: 1-78.

Stuhlmann, F., 1888. Vorläufiger Bericht über eine mit Unterstützung der Königlichen Akademie der Wissenschaften unternommene Reise nach OstAfrika, zur Untersuchung der Süsswasserfauna. Sber. K. preuss. Akad. Wiss., 1888 (49): 1255-1269. Sywula, T., 1970. Notes on Ostracoda. Part V and VI. Bull. Acad. pol. Sci. (Sér. Sci. biol.), 18: 79-86.

- , 1972. Notes on Ostracoda. Parts VII-X. Bull. Soc.
Amis Sci. Lett. Poznań (Sér. D), 12/13: 225-250. Tressler, W. L., 1937. Ostracoda. Int. Revue ges. Hydrobiol. Hydrogr., 34: 188-207.

—-, 1949. Freshwater Ostracoda from Brazil. Proc. U.S. natn. Mus., 100: 61-83.

-, 1950 . A synopsis of the ostracod genus Cypricercus, with a description of one new species from Wyoming. J. Wash. Acad. Sci., 40 (9): 291-295.

VÁvra, W., 1895. Die von Herrn Dr. F. Stuhlmann gesammelten Süsswasser-Ostracoden Zansibars. Jb. hamb. wiss. Anst., 12 (1): 1-23.

Victor, R. \& C. H. Fernando, 1979. On some freshwater ostracod type specimens from Indonesia. Can. J. Zool., 57 (1): 6-12.

- -, 1981a. Freshwater ostracods (Crustacea: Ostracoda) of the genus Strandesia Vavra, 1895 from Malaysia, Indonesia and the Philippines. Arch. Hydrobiol., Suppl. 58: 469-522.

- - 1981b. Freshwater ostracods (Crustacea: Ostracoda) of the subfamily Dolerocypridinae Triebel, 1961 from Southeast Asia. Zool. J. Linn. Soc., 72 (2): 107-116.

Victor, R., M. A. Paul * C. H. Fernando, 1980. Two new species of the genus Strandesia Vavra, 1895 (Ostracoda - Crustacea) from Kerala, southern India. Can. J. Zool., 58 (5): 727-734. 


\section{APPENDIX}

List of species belonging or ascribed to the genus Strandesia s.l., subgeneric status, distribution, and data on carapaces. Abbreviations used: ala = dorsal fin or comb on right valve; lip = anterior lip-like projection; obl. = oblique; s(e)-e(o) = sub(elongate)-elliptical(ovate), these shapes are illustrated in fig. $14 \mathrm{~L}$; trap. = trapezoidal; tub. = tuberculated.

Species

$$
\text { Subgenus } \begin{aligned}
& \text { Geographical distribution } \\
& \text { (authors) }
\end{aligned}
$$

\section{Carapace}

mean $\sigma^{\circ} \sigma$ length found (Q Q)

\begin{tabular}{l}
\hline S. anterotundata Rome \& De \\
Deckker, 1977 \\
S. asymmetros Rome, 1962 \\
S. bicornuta Hartmann, 1964 \\
S. bicuspis bicuspis (Claus, 1892) \\
S. bicuspis mucronata (Claus, 1892) \\
S. bornemiszai Klie, 1935 \\
(new name) \\
S. botosaneanui n. sp. \\
S. calapanensis Tressler, 1937 \\
S. camaguinensis Tressler, $1937=$ \\
syn. with: Tanycypris pellucida \\
S. carteri Klie, 1930 \\
S. caudata Klie, 1939 \\
S. cavernicola n. sp. \\
S. centrura Klie, 1940 \\
S. chondropherusa Rome, 1962 \\
S. clorocelis Anichini, 1967 \\
S. complexa Victor \& Fernando, \\
1981 \\
S. crassa Klie, 1939 \\
S. cyprinotoides Klie, 1938 \\
S. decorata (Sars, 1903 )
\end{tabular}

S. anterotundata Rome \& De

S. bicornuta Hartmann, 1964

Neocypris

Congo

Neocypris

Lake Tanganyika

- India

Acanthocypris Argentina

Acanthocypris Venezuela

- $\quad$ Kenya (high mountains)

( = Eucypris kraepelini Von Daday, 1910)

Acanthocypris Cuba

- Philippines (Victor \& Fernando, 1981a)

(Victor \& Fernando, 1981b)

Acanthocypris Gran Chaco, Paraguay

- Kenya (high mountains), Congo (Klie, 1944)

Acanthocypris Cuba, Haiti

- Brazil

Neocypris Congo

Neocypris Sardinia

- Philippines

Neocypris? Kenya (high mountains)

Neocypris? Congo

Neocypris Philippines, Malaysia, Java, Sulawesi (Victor \& Fernando, 1981a)

S. denticulata Tressler, 1949

S. diversicolor Klie, 1938

S. dorsolonga Rome, 1962

S.(?) dorsoviridis McKenzie, 1966

S. elliptica (Sars, 1901)

S. elongata Hartmann, 1964

$S$. nec episphaena (Tressler, 1949)

S. evae Gauthier, 1951

S. feuerborni Klie, 1932

$S$. flavescens Klie, 1932 = syn. with $S$. odiosa

S. freyi Victor \& Fernando, 1981 -

S. hancocki (Lowndes, 1931) -

S. hartmanni Victor, Paul \&

Fernando, 1980

\section{Acanthocypris? Brazil}

\section{- Congo}

- Lake Tanganyika, Congo

(Rome, 1964)

Australia (probably not a

Strandesia species)

\section{Neocypris Brazil}

India

- $\quad$ Brazil (probably related to

$S$. centrura, must be renamed)

- Senegal

(Victor \& Fernando, 1979)

Philippines

Uganda

India
Acanthocypris? Sumatra

$\begin{array}{rrrr} & \text { s-e } & 0.86 & - \\ \text { obl. } & \text { s-e } & 0.93 & - \\ 2 \text { spines } & \text { e-o } & 2.2 & + \\ \text { ala, } 1 \text { spine } & \text { e-e } & 2.40 & - \\ \text { ala, } 1 \text { spine } & \text { e-e } & - & - \\ & & - & - \\ & & & \\ & \text { e-e } & 1.50 & + \\ \text { e-o } & 0.88 & -\end{array}$

$\begin{array}{lll}\text { s-e } & 0.89 & - \\ \text { e-o } & 0.79 & - \\ \text { e-e } & 1.22 & -\end{array}$

lip, ala e-o $1.72 \quad-$

lip, ala s-o $2.3 \quad-$

tub. s-e $0.91-$

lip, ala s-o $1.54+$

2 spines trap. $0.95+$ 
Appendix (continued)

\section{Species}

Subgenus
Carapace (authors) mean o o

length found

(\% ㅇ)
S. indica Hartmann, 1964

S. intrepida Furtos, 1936

S. itapeva Tressler, 1949

S. kraepelini (Müller, 1906)

S. labiata Hartmann, 1964

$S$. lineata Victor \& Fernando, 1981a

S. longula n. sp.

S. mamarilorum Victor \&

Fernando, 1981a

S. mamarilorum sumatrana idem

S. marina Hartmann, 1965

S. mercatorum Vávra, 1895

S. minuta Klie, 1936

S. mollis (Furtos, 1936)

S. mucronata (Sars, 1901)

S. mulargia Anichini, 1967

S. mutica (Sars, 1901)

S. (Cypricercus) obliqua (Brady, 1868)

S. nec obliqua Klie, 1940

S. obtusata (Sars, 1901)

S. odiosa (Moniez, 1892)

S. ovalis Tressler, 1949

S. parva Hartmann, 1964

S. pedroensis Tressler, 1949

S. perakensis Victor \& Fernando, 1981a

S. pistrix n. sp.

S. postica Rome, 1962

S. prava Klie, 1935

S. purpurascens (Brady, 1886)

S. regularis Rome, 1962

$S$. reticulata (Von Daday, 1898)

S. riograndensis Tressler, 1949

$S$. rotunda (Tressler, 1949)

$S$. nec rotunda Hartmann, 1964

S. rouxi Méhes, 1939

S. saetosa Hartmann, 1964

\begin{tabular}{ll} 
Neocypris & India \\
- & Yucatan, Mexico \\
- & Brazil \\
- & Malaysia, Indonesia \\
- & India \\
\hline & Philippines
\end{tabular}

Acanthocypris West Indies

- Philippines, Malaysia, Sulawesi

- Sumatra

- Chile

- Zanzibar

Neocypris Kamerun, Kenya (high mountains) (Klie, 1939)

- Florida (could also be a

Bradleystrandesia)

- Brazil, Paraguay, Colombia

Neocypris Sardinia, Italy

Neocypris Brazil

Neocypris Europe, North Africa

Neocypris Brazil (could be $S$. sphaeroidea n. sp.)

Neocypris Brazil

- $\quad$ Sulawesi, Sumatra, S. India

(Victor \& Fernando, 1979, 1981a)

Acanthocypris? Brazil

- India

- Brazil ( = probably: Tanycypris meridana (Furtos, 1936))

- Malaysia, Kalimantan

- $\quad$ Haiti

- $\quad$ Lake Tanganyika

- Ivory Coast

- Sumatra, Ceylon, Java, Siam, India, Philippines, Malaysia (Victor \& Fernando, 1981a)

Neocypris Lake Tanganyika

- Ceylon, Java (Tressler, 1937;

Victor \& Fernando, 1981a)

Acanthocypris? Brazil

Neocypris? Brazil

Neocypris? India

Neocypris? New Caledonia (Pacific Islands) - India 
Appendix (continued)

\begin{tabular}{|c|c|c|c|c|}
\hline Species & Subgenus & $\begin{array}{l}\text { Geographical distribution } \\
\text { (authors) }\end{array}$ & Carapace & $\begin{array}{l}\text { mean } \sigma \circ \\
\text { length found } \\
(q \circ)\end{array}$ \\
\hline
\end{tabular}

S. sexpunctata Klie, 1932

S. sphacroidea $\mathbf{n}$. sp.

S. spinifera Hartmann $1964=$ Neocypris

syn. with $S$. weberi

S. spinulosa Bronstein, 1947

S. stocki n. sp.

S. strandesioides (Müller, 1898)

S. striatoreticulata Klie, $1932=$ syn. with $S$. wierzejski

S. sudanica Sywula, 1970

S. taeniata Vávra, 1895

S. tietensis Tressler, 1949

S. towoetensis Tressler, 1937

S. trichurensis Victor, Paul \&

Fernando, 1980

$S$. trispinosa (Pinto \& Purper, 1965)

$S$. trispinosa galantis $\mathbf{n}$. subsp.

S. tuberculata Hartmann, 1964

S. uenoi Klie, $1938=$ syn.

with $S$. calapanensis

S. ujijensis Rome, 1962

S. umbonata Victor \& Fernando, 1981 a

S. unguiculata Brehm, 1937

S. unicolor Klie, 1944

$S$. variegata (Sars, 1901)

S. vavrai (Müller, 1898)

S. venezolana $\mathrm{n} . \mathrm{sp}$.

S. vinciguerra Masi, 1905

S. vittata (Sars, 1903)

S. weberi (Moniez, 1892)

S. wierzejski (Grochmalicki, 1915) -

S. wolterecki Tressler, 1937
Java, Philippines (Victor a

Fernando, 1981a)

Marie-Galante, Antigua

(Victor \& Fernando, 1981a)

Uzbekistan, Tadzikistan,

Macedonia (Akatova, 1958;

Petkovski, 1964) probably syn.

with $S$. vinciguerra (Masi, 1905)

Neocypris Greater and some Lesser Antilles

Neocypris? Madagascar (Klie, 1938)

(Victor \& Fernando, 1981a)

- $\quad$ Sudan

- $\quad$ Zanzibar

- Sulawesi

- $\quad$ southern India

- $\quad$ southern Brazil

- Marie-Galante

India

(Victor \& Fernando, 1981a)

Neocypris Lake Tanganyika

W. Malaysia

- $\quad$ Angola

- Congo

Acanthocypris Brazil

Neocypris? Madagascar

Acanthocypris Venezuela

- S. Italy, Libya, Senegal,

Madagascar (Gauthier, 1951)

Neocypris China, Ceylon, Celebes (Victor

* Fernando, 1981a)

Celebes, W. Malaysia,

Philippines, Cambodja

(Hartmann, 1964; Victor \&

Fernando, 1979, 1981a)

Malaysia, Indonesia, Philippines

(Victor \& Fernando, 1981a)

Philippines, Indonesia, Malaysia

(Victor \& Fernando, 1981a)

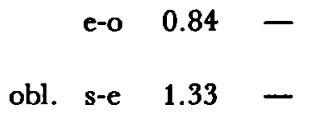

$\begin{array}{llll} & \text { s-e } & 0.91 & - \\ \text { ala } & \text { s-e } & 2.15 & \end{array}$

$\begin{array}{rccc} & \text { e-e } & 0.78 & + \\ & - & - & - \\ \text { e-e } & 1.49 & - \\ \text { s-e } & 0.73 & - \\ \text { many spines } & \text { s-o } & 0.74 & - \\ & & & \\ 3 \text { spines, ala } & \text { s-o } & 1.06 & - \\ & & & \\ 3 \text { spines, ala } & \text { s-o } & 1.09 & - \\ \text { thick tubercles } & \text { s-o } & 0.74 & -\end{array}$

obl. s-e $1.24 \quad-$

s-o 0.60 -

e-e $1.35=$

- -

e-e 1.44 -

s-e 1.33 -

e-o $1.75+$

e-o $1.2+$

obl. s-e $0.93-$

s-o $1.27 \quad-$

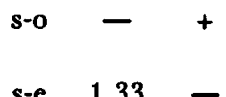

